\title{
1. Introduction to corruption in the Persian Gulf
}

Corruption, in some form or another, has existed since the earliest emergence of structured social organizations. Given the diversity of socio-economic and governance characteristics throughout the world, large differences exist in the level and typology of corruption. Moreover, researchers and institutions have defined corruption from different perspectives as they attempt to capture this diversity. Differences in the manifestation of corruption are particularly salient between developing and developed advanced economies. This becomes even more pronounced where there is a valuable and exhaustible national resource, such as oil or natural gas.

In this book, we discuss the impact of oil and gas endowment on the Persian Gulf oil-exporting countries (PGOEC). ${ }^{1}$ In Chapter 1, we discuss the nature of corruption and provide an introduction to its manifestations in the PGOEC. This chapter is divided into two parts: Part I provides an overview of some of the challenges in defining and measuring corruption; while Part II provides both a descriptive and analytical account of corruption in these countries. In Chapter 2, we focus on the treatment of corruption in Islam. Chapter 3 contains a review of the causes and consequences of corruption. In Chapter 4, we look at the impact of oil and gas dependency on corruption, and in Chapter 5, we examine the impact of corruption on economic growth and the role of the petroleum sector in the economies of the Persian Gulf. Finally, in Chapter 6, we examine the relationship of corruption, the natural resource curse and intergenerational equity, and offer an approach for transforming the curse into a blessing.

\section{PART I: DEFINITIONS AND MEASURES OF CORRUPTION}

\section{Definitions of Corruption}

There are numerous definitions, measurements and typologies of corruption. Many of these definitions were created by multilateral, 
international and government organizations, but there are a rapidly growing number of private market sector definitions of corruption that now serve as global indicators. Since the early 1990s, when corruption was seen as an important factor in international development and economics discourse, those working in the field and studying the issue have debated its precise definition. Perhaps the most widely cited definition and the one with the broadest consensus is 'the misuse of public office for private gain' (Kaufmann and Siegelbaum, 1997: 419; Treisman, 2000: 399). In addition, international organizations such as the United States Agency for International Development (USAID) and in some instances the World Bank use this definition to guide their own program of work in addressing corruption. Many argue that according to this conventional characterization of corruption, the public domain is distinctly separated from the private sector; in addition, public sector actors are the primary perpetrators, and corruption is universally for private gain or based on selfish motives. Moreover, the term misused (or the term abuse as used in some cases) generally implies the application of some kind of legal standard.

However, while this may be the most widely cited definition, questions have emerged about the scope and precision of this definition. For instance, some have argued that the definition of corruption should be expanded to include private sector actors rather then just those in the public sphere, and should necessarily include violations of certain norms beyond the legal standard. Moreover, while some contend that its scope should be broadened to take into consideration the various socio-cultural aspects of the phenomenum, others argue that a definition that is more limited in scope and standardized better serves the needs of researchers. Jain (2001: 73) sheds light on the importance of how corruption is defined when stating that although it may seem to be a simple issue of semantics, how corruption is defined provides the basis for what researchers choose to model and measure. Moreover, how corruption gets defined or conceptualized will ultimately guide the direction of anti-corruption legislation and other efforts to combat corruption.

Until recently, each multilateral agency had its own perspective and mechanism to measure, rank and record corruption. However, in early 2006, an International Financial Institutions Anti-Corruption Task Force was established by the major multilateral institutions (African Development Bank Group, Asian Development Bank, European Bank for Reconstruction and Development, European Investment Bank Group, Inter-American Development Bank Group, and the World Bank Group) in order to establish a consistent and harmonized approach to combat corruption in the activities and operations of member institutions. They 
jointly endorsed the following common principles and guidelines for investigations conducted by their respective inspection units: ${ }^{2}$

It was agreed upon that: 'critical to the success of a harmonized approach is a common understanding of the practices prohibited'. Hence the Task Force, in principle, ${ }^{3}$ agreed to the following 'standardized definitions of fraudulent and corrupt practices' for investigating such practices in activities financed by the member institutions:

1) A corrupt practice - is the offering, giving, receiving, or soliciting, directly or indirectly, anything of value to influence improperly the actions of another party.

2) A fraudulent practice - is any act or omission, including a misrepresentation, that knowingly or recklessly misleads, or attempts to mislead, a party to obtain a financial or other benefit or to avoid an obligation.

3) A coercive practice - is impairing or harming, or threatening to impair or harm, directly or indirectly, any party or the property of the party to influence improperly the actions of a party.

4) A collusive practice - is an arrangement between two or more parties designed to achieve an improper purpose, including influencing improperly the actions of another party. ${ }^{4}$

This work has complimented the Organisation for Economic Co-operation and Development's (OECD) Anti-bribery Convention signed by 38 countries. ${ }^{5}$ The OECD Working Group on Bribery examines acts of bribery involving foreign political parties, candidates for foreign public office, and foreign subsidiaries, among others. In addition, it also pays 'particular attention to the use of off-shore financial centers, private sector bribery, solicitation, whistleblower protection and practices that block effective investigation and prosecution of corruption cases'. ${ }^{6}$ The OECD's general view on corruption is stated as follows: 'corruption is typically the outcome of a dysfunctional governance system in which the linkages between the various institutional elements operate or malfunction in particular ways'. Most commonly, it defines corruption as the 'abuse of public office for private gain', or for the gain of particular groups (for example, a political party or an informal patronage network). The OECD, however, does not view corruption and weak governance as synonymous with one another. ${ }^{7}$

The World Bank has perhaps been the most visible multilateral voice speaking out against corruption. It argues that corruption deserves special attention because it works in 'insidious ways' as it tends to undermine the fabric of political, economic and social life. Corruption, as defined by the World Bank is:

the abuse of public office for private gain. This private gain could be in the form of money or favors for the benefit of family or friends - or for the benefit of 
special interest groups such as a political party seeking to obtain or retain power. Such behavior by persons concerned with the procurement process often leads to economic losses for the public. Thus, many lose for the benefit of a few. ${ }^{8}$

According to the World Bank: 'governance refers to the manner in which public officials and institutions acquire and exercise the authority to shape public policy and provide public goods and services. Corruption is one outcome of poor governance, involving the abuse of public office for private gain'. 9

The International Monetary Fund (IMF) defines the term governance as to:

encompass all aspects of the way a country is governed, including its economic policies and regulatory framework. Corruption is a narrower concept, which is often defined as the abuse of public authority or trust for private benefit. The Fund views theses two concepts as closely linked ... an environment characterized by poor governance offers greater incentives and more scope for corruption. Many of the causes of corruption are economic in nature, and so are its consequences - poor governance clearly is detrimental to economic activity and welfare. Because of their economic nature, issues related to governance and corruption often falls $[$ sic $]$ directly within the mandate and expertise of the IMF. ${ }^{10}$

The Asian Development Bank (ADB) Anticorruption Policy and the Inter-American Development Bank (IADB) both define corrupt and fraudulent practices under very similar terms (and similar to International Financial Institutions Anti-Corruption Task Force) as follows:

1) Corrupt practice - the offering, giving, receiving, or soliciting, directly or indirectly, anything of value to improperly influence the actions of another party (e.g. bribery, kickbacks, extortion, bid manipulation).

2) Fraudulent practice - any action, including misrepresentation, to obtain a financial or other benefit by deception (e.g. fraudulent claims like consultant timesheet, airfare, receipts/invoices; using lower rate personnel to perform work at higher rates; providing lower quality goods; false documents like curriculum vitae, bid security/bank guarantees, work certificates, financial statements, fictitious bids/ 'borrowing' names of firms; misrepresentation of educational background or full-time employment status).

3) Collusive practice - an arrangement between two or more parties designed to improperly influence the actions of another party (e.g. leaking of bid information, rigged specifications).

4) Coercive practice - impairing or harming, or threatening to impair or harm, directly or indirectly, any party or its property to improperly influence the actions of that party.

5) Conflict of interest - a situation in which a party has interests that could improperly influence that party's performance of its official duties or responsibilities, contractual obligations, or compliance with applicable laws and regulations. ${ }^{11}$ 
The World Trade Organization's (WTO) view on corruption, as to be expected, takes on a trade-slanted definition. An example of the broad range of issues the WTO squeezes under corruption are those that are trade-related barriers, that is, quotas, since they restrict imports or exports (limit supply) and they can artificially raise prices, creating abnormally large profits (that is, quota rent). It is the WTO's view that those profits can be used to influence policies, that is, lobbying, which for example can influence and provide opportunities for corruption in the allocation of quotas. The WTO also considers 'transparency, such as, making available to the public all information on trade regulations, other aspects of trade facilitation, clearer criteria for regulations dealing with the safety and standards of products, and non-discrimination also help by reducing the scope for arbitrary decision-making and cheating' ${ }^{12}$ In principle, the WTO considers corruption an economic act through the supply and demand mechanism, that is:

supply side corruption emanates from contractors seeking to bribe or collude in some way with government officials willing to take advantage of an opportunity offered to them ... [while] demand side corruption involves resources sought to enrich the government official in some way or to sustain a political position or party outside of accepted means..$^{13}$

The United Nations under its UN Development Programme (UNDP) in its July 1998 report, 'Fighting Corruption to Improve Governance', defined corruption as: 'the misuse of public power, office or authority for private benefit - through bribery, extortion, influence peddling, nepotism, fraud, speed money or embezzlement. Although corruption is often considered a sin of government and public servants, it also prevails in the private sector.' ${ }^{\prime 4}$

There are many other noteworthy multilateral institutions, such as the Bank for International Settlements (BIS), and regional institutions such as the European Union (Convention on the Fight Against Corruption), European Bank for Reconstruction and Development (EBRD), European Investment Bank (EIB), European Central Bank (ECB, and the Council of Europe Anti-corruption Evaluations that also are pushing forward their own specific definitions of corruption. The major definitions and types of corruption as identified by some of the leading institutions in the field are summarized in Table 1.1.

\section{Measuring Corruption}

Attempting to define and measure corruption across comparable countries is already a challenging endeavor. It is even more problematic to design a 


\section{Table 1.1 Definitions of Corruption by Multilateral and International Institutions}

\begin{tabular}{l} 
Type \\
\hline 'According \\
to rule' \\
corruption \\
'Against \\
the rule' \\
corruption
\end{tabular}

\begin{tabular}{ll} 
Definition & Source \\
\hline The misuse of entrusted power for private gain & $\begin{array}{l}\text { Transparency } \\
\text { International }\end{array}$
\end{tabular}

Facilitation payments, where a bribe is paid to

Transparency receive preferential treatment for something International that the bribe receiver is required to do by law.

The bribe paid to obtain services the bribe

Transparency receiver is prohibited from providing.

International

Corruption is one outcome of poor

WB

governance, involving the abuse of public office for private gain

Corruption is an outcome of a dysfunctional governance system in which the linkages between the various institutional elements operate or malfunction in particular ways. Corruption is defined as the 'abuse of public office for private gain', or for the gain of particular groups (for example, a political party or an informal patronage network). Corruption and weak governance are not synonymous, however.

$\begin{array}{lll}\begin{array}{l}\text { Petty (or } \\ \text { street-level) } \\ \text { corruption }\end{array} & \begin{array}{l}\text { Petty corruption is most likely to confront } \\ \text { people in their daily lives and be most } \\ \text { immediately damaging for the poor. Critical to } \\ \text { changing the structural context for corruption. }\end{array} & \begin{array}{l}\text { Overseas } \\ \text { Development } \\ \text { Institute }\end{array} \\ \begin{array}{lll}\text { Grand } \\ \text { corruption }\end{array} & \begin{array}{l}\text { Kickbacks in procurement contracts, etc. } \\ \text { Grand corruption can in turn be subdivided } \\ \text { between '10 percent' corruption and }\end{array} & \begin{array}{l}\text { Overseas } \\ \text { Development } \\ \text { 'predatory corruption'. While the former }\end{array} \\ & \begin{array}{l}\text { Institute } \\ \text { the latter means that in most cases, no road is }\end{array} & \\ & \begin{array}{l}\text { built. Predatory corruption is widely seen as } \\ \text { the form of corruption, which is overall most } \\ \text { damaging to development and to the prospects }\end{array} & \\ & \text { for sustainable poverty reduction. } & \end{array}$


Table 1.1 (continued)

\begin{tabular}{ll}
\hline Type & Definition \\
\hline $\begin{array}{l}\text { Centralized } \\
\text { and }\end{array}$ & $\begin{array}{l}\text { In some contexts, a bribe may be required } \\
\text { to obtain a license or to speed up an import } \\
\text { predictable } \\
\text { types of }\end{array}$ \\
$\begin{array}{l}\text { procedure with the outcome being largely } \\
\text { porruption }\end{array}$ & $\begin{array}{l}\text { need to be bribed and the outcome remains } \\
\text { uncertain. The former is most often associated } \\
\text { with centralized states with a limited set of } \\
\text { power-holders. }\end{array}$
\end{tabular}

Decentralized and erratic corruption
Dispersed and erratic corruption is often a marker of weak(ened) state capacity; and likely to require a different set of political and policy responses.

Corruption is the misuse of public power, office or authority for private benefit - through bribery, extortion, influence peddling, nepotism, fraud, speed money or embezzlement. Although corruption is often considered a sin of government and public servants, it also prevails in the private sector.

Corruption $=($ Monopoly + Discretion $)-$ (Accountability + Integrity + Transparency

Corruption is the use of public resources for private gain - a betrayal of the public confidence invested in individuals with access to public resources.

Actual or potential corruption in the form of excessive patronage, nepotism, job reservations, 'favor-for-favors', secret party funding, and suspiciously close ties between politics and business. In our view these insidious sorts of corruption are potentially of much greater risk to foreign business in that they can lead to popular discontent, unrealistic and inefficient controls on the state economy, and encourage the development of the black market
Source

Overseas

Development

Institute

Overseas

Development

Institute

UNDP

UNDP

UNDP

The PRS

Group

(private riskassessment

firm) 
Table 1.1 (continued)

\begin{tabular}{|c|c|c|}
\hline Type & Definition & Source \\
\hline & $\begin{array}{l}\text { Corruption is the misuse of public office } \\
\text { for private gain. It encompasses abuses by } \\
\text { government officials such as embezzlement } \\
\text { and nepotism, as well as abuses linking } \\
\text { public and private actors such as bribery, } \\
\text { extortion, influence peddling, and fraud. } \\
\text { Corruption arises in both political and } \\
\text { bureaucratic offices and can be petty or } \\
\text { grand, organized or unorganized. Though } \\
\text { corruption often facilitates criminal activities } \\
\text { such as drug trafficking, money laundering, } \\
\text { and prostitution, it is not restricted to these } \\
\text { activities. For purposes of understanding the } \\
\text { problem and devising remedies, it is important } \\
\text { to think of crime and corruption as two } \\
\text { separate problems. }\end{array}$ & USAID \\
\hline $\begin{array}{l}\text { Corrupt } \\
\text { practice }\end{array}$ & $\begin{array}{l}\text { Corrupt practice - the offering, giving, } \\
\text { receiving, or soliciting, directly or indirectly, } \\
\text { anything of value to improperly influence } \\
\text { the actions of another party (e.g. bribery, } \\
\text { kickbacks, extortion, bid manipulation) }\end{array}$ & $\mathrm{ADB}$ \\
\hline \multirow[t]{2}{*}{$\begin{array}{l}\text { Fraudulent } \\
\text { practice }\end{array}$} & $\begin{array}{l}\text { Fraudulent practice - any action, including } \\
\text { misrepresentation, to obtain a financial or } \\
\text { other benefit by deception (e.g. fraudulent } \\
\text { claims like consultant timesheet, airfare, } \\
\text { receipts/invoices; using lower rate personnel to } \\
\text { perform work at higher rates; providing lower } \\
\text { quality goods; false documents like curriculum } \\
\text { vitae, bid security/bank guarantees, } \\
\text { work certificates, financial statements, } \\
\text { fictitious bids/'borrowing' names of firms; } \\
\text { misrepresentation of educational background } \\
\text { or full-time employment status) }\end{array}$ & $\mathrm{ADB}$ \\
\hline & $\begin{array}{l}\text { or Collusive practice - an arrangement } \\
\text { between two or more parties designed to } \\
\text { improperly influence the actions of another } \\
\text { party (e.g. leaking of bid information, rigged } \\
\text { specifications) }\end{array}$ & $\mathrm{ADB}$ \\
\hline
\end{tabular}


Table 1.1 (continued)

\begin{tabular}{|c|c|c|}
\hline Type & Definition & Source \\
\hline \multirow[t]{2}{*}{$\begin{array}{l}\text { Coercive } \\
\text { practice }\end{array}$} & $\begin{array}{l}\text { Coercive practice - impairing or harming, } \\
\text { or threatening to impair or harm, directly } \\
\text { or indirectly, any party or its property to } \\
\text { improperly influence the actions of that party }\end{array}$ & ADB \\
\hline & $\begin{array}{l}\text { Corruption is the abuse of entrusted power } \\
\text { for private financial or non-financial gain. } \\
\text { It diverts resources from their proper use, } \\
\text { distorts competition and creates gross } \\
\text { inefficiencies in both the public and private } \\
\text { sectors. }\end{array}$ & $\begin{array}{l}\text { International } \\
\text { Chamber of } \\
\text { Commerce }\end{array}$ \\
\hline Bribery & $\begin{array}{l}\text { Bribery is an offer or the receipt of any gift, } \\
\text { loan, fee, reward or other advantage to or } \\
\text { from any person as an inducement to do } \\
\text { something, which is dishonest or illegal. } \\
\text { Corruption can occur in form of bribery, bribe } \\
\text { solicitation or extortion. }\end{array}$ & $\begin{array}{l}\text { International } \\
\text { Chamber of } \\
\text { Commerce }\end{array}$ \\
\hline $\begin{array}{l}\text { Bribe } \\
\text { solicitation }\end{array}$ & $\begin{array}{l}\text { Bribe solicitation is the act of asking or } \\
\text { enticing another to commit bribery }\end{array}$ & $\begin{array}{l}\text { International } \\
\text { Chamber of } \\
\text { Commerce }\end{array}$ \\
\hline Extortion & $\begin{array}{l}\text { When bribe solicitation is accompanied by } \\
\text { threats it becomes extortion }\end{array}$ & $\begin{array}{l}\text { International } \\
\text { Chamber of } \\
\text { Commerce }\end{array}$ \\
\hline $\begin{array}{l}\text { Whistle- } \\
\text { blowing }\end{array}$ & $\begin{array}{l}\text { Whistle-blowing is a procedure that is } \\
\text { voluntarily implemented by a public or } \\
\text { private enterprise and which allows employees } \\
\text { to expose serious concerns (whether they } \\
\text { are established or soundly perceived) that } \\
\text { may result in a breach of the law or of the } \\
\text { company's internal regulations, serious harm } \\
\text { to company activities by engaging its civil and } \\
\text { criminal responsibility. }\end{array}$ & $\begin{array}{l}\text { International } \\
\text { Chamber of } \\
\text { Commerce }\end{array}$ \\
\hline $\begin{array}{l}\text { Corruption } \\
\text { vs. Public } \\
\text { Integrity }\end{array}$ & $\begin{array}{l}\text { Corruption here is defined as the abuse of } \\
\text { power for private gain from public office. } \\
\text { Corruption erodes public trust in government, } \\
\text { undermines the rule of law, weakens the state } \\
\text { and hinders economic growth by }\end{array}$ & $\begin{array}{l}\text { Global } \\
\text { Integrity }\end{array}$ \\
\hline
\end{tabular}


Table 1.1 (continued)

\begin{tabular}{ll}
\hline Type & Definition \\
\hline & discouraging investment. Public integrity is \\
the opposite of corruption. It is a holistic & \\
concept that champions the public interest \\
over the personal and refers to mechanisms \\
that promote government honesty, \\
openness, accountability, responsiveness and \\
transparency
\end{tabular}

single index to measure and rank corruption globally, for countries that are very dissimilar. There are numerous methods to measure corruption; however, there are three broad categories of corruption and corruptionrelated indicators: (1) those developed by private political risk firms; (2) perception-based indices designed by advocacy groups; and (3) broad governance indicators that are seen as related to corruption. Each approach has its associated limitations and strengths. Moreover, each of these established corruption and corruption-related indicators and indices also differs in certain key dimensions, that is, the precision and scope of the definition of corruption, statistical and survey methodology, level of transparency, and the like. They vary in their attempt to assess the incidence of corruption, that is, the impact of corruption on business, or the existence of government and other mechanisms believed to affect the prevalence of corrupt transactions. ${ }^{15}$

\section{Indices developed by private political risk firms}

The first type of indicator, primarily designed by private risk assessment firms, such as the Economist Intelligence Unit (EIU) and Political Risk Services (PRS), collect data from a network of correspondents with country-specific expertise, in addition to using business surveys and other quantitative sources of data. By assessing the relative incidence of corrupt transaction, PSR's International Country Risk Guide (ICRG) corruption indicator is purported to capture the likelihood that high-level government authorities will extract illegal payments and the extent to which such payments are expected to exist throughout the government hierarchy. ${ }^{16}$ Since most subscribers are typically private sector actors (banks, multinational corporations and international investors), these rating systems, as to be expected, focus primarily on issues of corruption most pertinent to business and foreign investment, measuring the quality or attractiveness of the business environment and the degree to which business activity can 
be expected to involve corrupt or potentially illegal transactions. In the ICRG, corruption is measured as a single dimension in a broader index of political risk, which is a component of an overall risk rating. The index is based on a scale of 0-6 with a lower score representing that 'high government officials are likely to demand special payments' and 'illegal payments are generally expected throughout the lower levels of government' and the form of 'bribes connected to import and export licenses, exchange controls, tax assessments, policy, protection, or loans'. ${ }^{17}$ Generally, the methodologies employed by these rating systems are far less transparent then those employed by advocacy groups.

\section{Perception-based indices designed by advocacy groups}

The second set of indicators, typically developed by advocacy groups such as Transparency International (TI) and the World Bank Institute (WBI), measure corruption based on a series of surveys, which are reported by the public at large and by business representatives. Some surveys focus on business leaders' direct experience with issues related to corruption, while others solicit their 'expert opinion' or perception of corruption in a particular country. Perception-based indicators are based on the assumption that the perception of a specific set of respondents (business leaders, public servants, and so on) is accurately correlated to levels or patterns of corruption. Similarly to indicators developed by private political risk firms, the scope of survey questions (and thereby the implicit definition of corruption) designed by advocacy groups also illicits responses most relevant to their constituents and their mission; whether it be to assess the need for technical assistance in the areas of governance, to determine a country's eligibility for international aid, or simply to raise international awareness of corruption.

The initial goal for the TI Corruption Perception Index (CPI) was to raise global awareness of corruption and to provide researchers with data for evaluating the causes and consequences of corruption. ${ }^{18}$ It has emerged as the most popular quantitative indicator of cross-country corruption comparisons. The CPI ranks more than 150 countries on the perceived level of corruption, as determined by expert assessments and opinion surveys. Unlike private sector risk analysis firms, TI's corruption index is not based on information from its own experts. Instead, it is constructed on the basis of a weighted average of between three and 16 sources from about nine different organizations, depending on the country and available data. A score of 10 represents total absence of corruption in a country, while 0 indicates that a country is perceived as completely corrupt.

The World Bank Institute's Control of Corruption Index (CCI) has 
attempted to build on and improve on Transparency International's corruption measurement. Both organizations use a composite set of indices to develop a single standardized measurement. However, there are some important differences between these indicators. While the CPI requires that country ratings be based on at least three survey sources, the CCI requires only one source per country. Accordingly, it has employed a broader definition of corruption and includes most cross-country indices reporting rankings on some aspect of corruption. ${ }^{19}$ Moreover, the designers of the Control of Corruption Index (Kaufmann, Kraay and Mastruzzi) argue that TI's approach presents some limitations, as the presence of select and minimal data is not randomly distributed. Therefore, those countries with the poorest institutional capacity, questionable mechanisms of governance, and perhaps the highest levels of corruption will most likely have the fewest sources of corruption ratings. The CCI is measured in units ranging from -2.5 to 2.5 , with higher values corresponding to better governance.

As to be expected, there have been a number of criticisms of these perception-based corruption indices. While the composite method may make for a more accurate index because measurement errors are likely to be minimized by aggregating data from multiple sources,$^{20}$ many professionals have criticized the methodology. Some of these indices are also more (or less) appropriate for measuring changes over time and comparisons between countries. As organizations periodically attempt to improve statistical methodology, such changes may ultimately limit cross-country and time-series comparability. Drawing comparisons between countries is further hampered because the number of sources and the sources of data themselves are often inconsistent across countries. Moreover, varying sources may measure different dimensions of corruption and may define corruption differently; composite indices therefore have no clear definition. Perhaps the most widely cited criticism of these indices is that they are based on subjective perception rather than on some sort of empirical evaluation of corruption. For instance, during periods of rapid economic growth due to high oil export revenues, respondents in oil-exporting countries may attribute the increased ease of doing business to decreased corruption. Similarly, increased media hype as a result of a government initiative to tackle corruption may in fact exacerbate the perception of corruption. However, it is clear that given the inherent insidiousness of corruption, an empirical rating system is not always possible, particularly on a large scale. Finally, while corruption may take different forms (that is, petty corruption, a 'corrupt legal system' and so on), most corruption indices do not describe which forms of corruption may exist in a particular country. 


\section{Broad governance indicators thought to be related to corruption}

The third category of indicators is also typically designed by advocacy organizations; with corruption, however, as a component of a broader set of governance indices. These indicators generally describe corruption as a function of institutional arrangements and government policies - such as the presence of institutional bureaucracy, business and regulatory environment, and economic, political and civil freedoms, and so on. While such indicators may not be a measure of corruption per se, to some the benefits of empirically driven data outweigh the usefulness of perceptionbased indices. Many have criticized governance indicators as representing cultural or political biases about how public institutions and systems of governance should be organized. Tables 1.2-1.4 summarize the various institutions that measure government, legal and political corruption.

\section{Categories of Corruption}

Research shows that corruption is manifested in different shapes and forms in different regions of the world, but typically with considerable overlap among regions. ${ }^{21}$ One common category of corruption is usually known as organized or centralized or 'oligarchs' corruption. This tends to occur in countries with dictatorships, one-family rule, other forms of autocratic rulers and their associated group of family and elites. This organized form of corruption typically pursues de facto control of natural resources, financial and investment institutions, property agencies and other specific sectors of the economy. A prime example of this type of organized or centralized corruption category existed in Indonesia under the Suharto government from 1967 to 1998.

Another common category of corruption, which can coexist with organized and centralized corruption, is what is commonly known as 'diffused' corruption. This form of corruption is demographically widespread and is usually undertaken by bureaucrats and civil servants from the highest to the lowest levels. Examples of such transactions are embedded in a broader set of activities, that is, those that favor various groups of privileged insiders, such as industrialists receiving favorable regulations, public employees receiving high salaries, job security and perks, certain localities favored by those in power. They tend to be manifested in very specific types of behaviors, such as: assessment and payment of various kinds of taxes and government fees; trying to receive everyday public services; protecting one's property rights, such as preventing an unauthorized occupation of one's property or getting a delinquent tenant evicted from one's property; a transaction between a food adulterer and an official who is responsible for food safety; or even something as ordinary as getting a vehicle registered 
Table 1.2 Measuring Government Corruption

\begin{tabular}{|c|c|c|}
\hline Type & Definition & Source \\
\hline Governance & $\begin{array}{l}\text { Governance is the traditions and } \\
\text { institutions by which authority in a country } \\
\text { is exercised for the common good. This } \\
\text { includes the process by which those in } \\
\text { authority are selected, monitored and } \\
\text { replaced (the political dimension); the } \\
\text { government's capacity to manage its } \\
\text { resources effectively and implement sound } \\
\text { policies (the economic dimension); and } \\
\text { the respect of citizens and the state for the } \\
\text { country's institutions (the institutional } \\
\text { respect dimension) }\end{array}$ & $\begin{array}{l}\text { WB Control } \\
\text { of Corruption } \\
\text { Governance } \\
\text { Indicators } \\
\text { (Kaufmann, } \\
\text { Kraay and } \\
\text { Mastruzzi) }\end{array}$ \\
\hline $\begin{array}{l}\text { Public } \\
\text { Governance }\end{array}$ & $\begin{array}{l}\text { 'Public governance' is the response to the } \\
\text { challenges of globalization in terms of } \\
\text { effectiveness, efficiency and responsiveness } \\
\text { facing the public sector. It also addresses } \\
\text { the dramatic changes that regulation and } \\
\text { management of society have undergone } \\
\text { over the past decades. Public governance } \\
\text { seeks to understand and conceptualize } \\
\text { appropriate forms of state-society relations } \\
\text { that are capable of responding to this } \\
\text { complex environment. By addressing } \\
\text { institutional capacity and constituting the } \\
\text { framework for equitable and legitimate } \\
\text { political structures, it has become a key } \\
\text { concept for public management reform }\end{array}$ & $\begin{array}{l}\text { Basel } \\
\text { Institute on } \\
\text { Governance }\end{array}$ \\
\hline Rent-seeking & $\begin{array}{l}\text { It is the extra amount paid (over what } \\
\text { would be paid for the best alternative use) } \\
\text { to somebody or for something useful whose } \\
\text { supply is limited either by nature or through } \\
\text { human ingenuity. }\end{array}$ & IMF \\
\hline $\begin{array}{l}\text { Government } \\
\text { effectiveness }\end{array}$ & $\begin{array}{l}\text { Measuring the quality of public services, the } \\
\text { quality of the civil service and the degree of } \\
\text { its independence from political pressures, } \\
\text { the quality of policy formulation and } \\
\text { implementation, and the credibility of the } \\
\text { government's commitment to such policies }\end{array}$ & $\begin{array}{l}\text { WB Control } \\
\text { of Corruption } \\
\text { Governance } \\
\text { Indicators } \\
\text { (Kaufmann, } \\
\text { Kraay and } \\
\text { Mastruzzi) }\end{array}$ \\
\hline
\end{tabular}


Table 1.2 (continued)

\begin{tabular}{|c|c|c|}
\hline Type & Definition & Source \\
\hline State capture & $\begin{array}{l}\text { The survey design permits an in-depth } \\
\text { empirical analysis of governance and } \\
\text { corruption, unbundling governance into } \\
\text { its component dimensions. This allows a } \\
\text { more detailed quantitative assessment of } \\
\text { corruption, a more nuanced understanding } \\
\text { of the causes of the problem and as a result } \\
\text { a stronger foundation for policy advice. } \\
\text { Particular attention is paid to 'state capture' } \\
\text { by parts of the corporate sector (i.e. the } \\
\text { propensity of firms to shape the underlying } \\
\text { 'rules of the game' including 'purchase' of } \\
\text { legislation and court decisions). }\end{array}$ & $\begin{array}{l}\text { WB Business } \\
\text { Environment } \\
\text { and } \\
\text { Enterprise } \\
\text { Performance } \\
\text { Survey } \\
\text { (BEEPS) }\end{array}$ \\
\hline $\begin{array}{l}\text { Voice and } \\
\text { accountability }\end{array}$ & $\begin{array}{l}\text { Measuring the extent to which a country's } \\
\text { citizens are able to participate in selecting } \\
\text { their government, as well as freedom of } \\
\text { expression, freedom of association and a } \\
\text { free media. }\end{array}$ & $\begin{array}{l}\text { WB Control } \\
\text { of Corruption } \\
\text { Governance } \\
\text { Indicators } \\
\text { (Kaufmann, } \\
\text { Kraay and } \\
\text { Mastruzzi) }\end{array}$ \\
\hline $\begin{array}{l}\text { Control of } \\
\text { corruption }\end{array}$ & $\begin{array}{l}\text { Measuring the extent to which public power } \\
\text { is exercised for private gain, including both } \\
\text { petty and grand forms of corruption, as well } \\
\text { as 'capture' of the state by elites and private } \\
\text { interests }\end{array}$ & $\begin{array}{l}\text { WB Control } \\
\text { of Corruption } \\
\text { Governance } \\
\text { Indicators } \\
\text { (Kaufmann, } \\
\text { Kraay and } \\
\text { Mastruzzi) }\end{array}$ \\
\hline $\begin{array}{l}\text { Regulatory } \\
\text { quality }\end{array}$ & $\begin{array}{l}\text { Measuring the ability of the government } \\
\text { to formulate and implement sound policies } \\
\text { and regulations that permit and promote } \\
\text { private sector development }\end{array}$ & $\begin{array}{l}\text { WB Control } \\
\text { of Corruption } \\
\text { Governance } \\
\text { Indicators } \\
\text { (Kaufmann, } \\
\text { Kraay and } \\
\text { Mastruzzi) }\end{array}$ \\
\hline
\end{tabular}


Table 1.3 Measuring Rule of Law and Corruption

\begin{tabular}{lll}
\hline Type & Definition & Source \\
\hline $\begin{array}{l}\text { Rule of } \\
\text { law }\end{array}$ & $\begin{array}{l}\text { Measuring the extent to which agents } \\
\text { have confidence in and abide by the rules } \\
\text { of society, and in particular the quality of } \\
\text { contract enforcement, the police and the } \\
\text { courts, as well as the likelihood of crime and } \\
\text { violence }\end{array}$ & $\begin{array}{l}\text { WB Control } \\
\text { of Corruption } \\
\text { Governance } \\
\text { Indicators } \\
\text { (Kaufmann, Kraay } \\
\text { and Mastruzzi) }\end{array}$ \\
$\begin{array}{l}\text { Conflict } \\
\text { of interest }\end{array}$ & $\begin{array}{l}\text { Conflict of interest - a situation in which } \\
\text { a party has interests that could improperly } \\
\text { influence that party's performance of its } \\
\text { official duties or responsibilities, contractual } \\
\text { obligations, or compliance with applicable } \\
\text { laws and regulations. }\end{array}$ & $\begin{array}{l}\text { WB Control } \\
\text { of Corruption } \\
\text { Governance } \\
\text { Indicators }\end{array}$ \\
\end{tabular}

or a passport issued. Corruption of this kind is not centrally organized or coordinated in any significant manner by actors, including the politicians, even though they usually share its proceeds. ${ }^{22}$

\section{PART II: AN INTRODUCTION TO CORRUPTION IN THE PERSIAN GULF}

\section{Manifestation of Corruption}

In the second part of this chapter, we provide an overview of some of the manifestations of corruption, with a focus on the Persian Gulf oil exporters. Corruption becomes more pronounced the longer the same party or ruler remains in power. In the major Islamic oil-exporting countries of the Persian Gulf (PGOEC), continuous rule by the same party or ruler has been prevalent for decades and, in fact, in every case, except Iran and Iraq, since their formation as countries. ${ }^{23}$ Even in the case of these two exceptions, longevity of rule has existed in other ways. For example, Iran claims that elections have changed governments, when in fact the religious clerics have been the backbone of the real power ever since the Iranian Revolution in 1979; and before that it was the Pahlavi dynasty from World War II on. In Iraq, the Baath Party held power for about 35 years.

Support for continuous rule in the PGOEC has come from different sources. In both Saudi Arabia and Iran since 1979, the ruling classes have sought legitimacy through support from the religious establishment rather 
Table 1.4 Measuring the Political Corruption

\begin{tabular}{|c|c|c|}
\hline Type & Definition & Source \\
\hline $\begin{array}{l}\text { Political } \\
\text { stability } \\
\text { and absence } \\
\text { of violence }\end{array}$ & $\begin{array}{l}\text { Measuring perceptions of the likelihood that the } \\
\text { government will be destabilized or overthrown } \\
\text { by unconstitutional or violent means, including } \\
\text { domestic violence and terrorism }\end{array}$ & $\begin{array}{l}\text { WB Control } \\
\text { of Corruption } \\
\text { Governance } \\
\text { Indicators } \\
\text { (Kaufmann, } \\
\text { Kraay and } \\
\text { Mastruzzi) }\end{array}$ \\
\hline Lobbying & $\begin{array}{l}\text { The EBRD-World Bank Business Environment } \\
\text { and Enterprise Performance Survey (BEEPS) } \\
\text { compiles the experiences of approximately } 20000 \\
\text { firms in } 26 \text { transition countries plus Turkey in } \\
\text { three rounds: } 1999,2002 \text { and } 2005 \text {. The survey } \\
\text { examines the quality of the business environment } \\
\text { as determined by a wide range of interactions } \\
\text { between firms and the state. }\end{array}$ & $\begin{array}{l}\text { WB Business } \\
\text { Environment } \\
\text { and } \\
\text { Enterprise } \\
\text { Performance } \\
\text { Survey } \\
\text { (BEEPS) }\end{array}$ \\
\hline $\begin{array}{l}\text { Political } \\
\text { party } \\
\text { financing }\end{array}$ & $\begin{array}{l}\text { The Global Integrity Report is a tool for } \\
\text { understanding governance and anti-corruption } \\
\text { mechanisms at the national level written } \\
\text { by local researchers and journalists. Each } \\
\text { country assessment contained in the Global } \\
\text { Integrity Report comprises two core elements: } \\
\text { a qualitative Reporter's Notebook and a } \\
\text { quantitative Integrity Indicators scorecard, } \\
\text { the data from which is aggregated and used } \\
\text { to generate the cross-country Global Integrity } \\
\text { Index. An Integrity Indicators scorecard } \\
\text { assesses the existence and effectiveness of and } \\
\text { citizen access to key governance and anti- } \\
\text { corruption mechanisms through more than } 300 \\
\text { actionable indicators. It examines issues such as } \\
\text { transparency of the public procurement process, } \\
\text { media freedom, asset disclosure requirements } \\
\text { and conflicts of interest regulations. }\end{array}$ & $\begin{array}{l}\text { UNDP } \\
\text { and Global } \\
\text { Integrity }\end{array}$ \\
\hline
\end{tabular}

than from the population at large, that is, through free and open elections and an active civil society. In the smaller Persian Gulf oil-exporting countries (Kuwait, Qatar and the UAE) governments have traditionally derived their authority through support not only from the religious establishment but also from the merchant class. However, in all these economies, to 
one degree or another, as oil has gained economic dominance in the economic system, the legitimacy of the ruling class has become closely associated with their ability to provide material well-being to citizens no matter how large the economic costs. ${ }^{24}$ As such, it is not surprising that the form of political control in the PGOEC has ultimately been the decisive determinant of how oil revenues have been managed.

Although discussed in more depth in Chapter 2, on Islam and corruption, it is important to note that the relationship between Islam and corruption is particularly pertinent here as the entire region is an Islamic zone and generally perceived as the heart of Islam because of the location of Mecca and Medina in Saudi Arabia. It is general knowledge that corruption and corrupt practices are un-Islamic and are unambiguously condemned in the Quran. In Islam, individuals are expected to work hard for economic gain, compete in business, own private property, and share risks in investment. It was understood that economic and emotional strains of poverty may compel an individual to resort to unhealthy or unethical means of earning an income. Thus the principles of an Islamic economic system were formulated to ensure the availability of education and equal employment opportunity for all, poverty reduction and prevention, and continuous social and intellectual development for all individuals. ${ }^{25}$ As such, one of the critical areas in gauging Islamic governments is the following: quality of policy formulation, equal opportunity for all, economic growth and prosperity, and economic justice. This is further reinforced by emphasis in Islam on wealth distribution. ${ }^{26}$ Abbas Mirakhor has summarized the notion of equitable income succinctly in his statement:

Islam asserts unambiguously that poverty is neither caused by scarcity and paucity of natural resources, nor is due to the lack of proper synchronization between the mode of production and the relation of distribution, but as a result of waste, opulence, extravagance, and nonpayment of what rightfully belongs to the less able segments of the society. This position is illustrated by the Prophetic saying that: 'Nothing makes a poor man starve except that with which a rich person avails in luxury. ${ }^{27}$

\section{Oil-related corruption in the Persian Gulf}

In the oil-exporting countries of the Persian Gulf, the depletion of oil and gas has been a major source of income and wealth over the last 50 or so years and will most likely continue to be so for some time to come. Oil and gas resources are natural depletable resources and should, according to Islam, benefit all citizens of this and future generations equally. Thus it is not unreasonable for the population to expect a more even distribution of wealth in these Islamic oil- and gas-exporting countries than in other countries because they rely heavily on oil and gas as a source of income. 
This, in fact, has been the foundation of the argument used by governments in the region to support their widely used socio-economic policy tool of heavily subsidizing the population (health, education, housing, and so on) using oil and gas revenues.

The most persistent allegations of corruption against the governments in the PGOEC has been that ruling public officials have for decades taken a portion, in some cases a significant portion, of the oil wealth for personal use in addition to receiving their sanctioned stipends. Readily available data confirm that oil and gas revenues constitute a significant component of gross domestic product (GDP) as other non-petroleum and non-gas industries have played a relatively smaller part than in nonresourced based countries in the generation of GDP. It is because of the unique manner in which natural resources are conceived in Islam that this has become an issue for regional corruption experts. Although many of these governments have provided substantial infrastructure development and subsidized healthcare, housing, education and even jobs for decades, which are one way of sharing the oil and gas revenues amongst the population, this has not benefited all citizens equally and the interests of future generations have not been explicitly addressed.

However, for the oil-rich economies the effect of corruption on human development is sometimes disguised by oil windfalls used to subsidize these generous social welfare programs. To the extent that the PGOEC are able to continue to develop in the areas of health, education, infrastructure and employment guarantees during boom periods of oil-driven development, few question the conspicuous wealth accumulation of those in power. However, as oil prices fall, development lags and the effects of corruption become more prominent, greater tension between the rulers and the general population arises. It is then that the disparity in lifestyles, existence of poverty and lack of equal access to economic opportunities all point to an un-Islamic distribution of oil wealth, especially if the welfare of future generations is not taken into account.

There is of course no direct statistical data available to substantiate these allegations but the mass media more often than not points to visible signs of the excessive and inappropriate use of public funds. In post-invasion Iraq, the number and size of Saddam Hussein's palaces are well documented. In Saudi Arabia, the lavish palaces of the senior Al-Saud princes are numerous, albeit behind very high walls, as are their foreign real estate holdings. In Iran, the income disparity between North and South Teheran as seen in residences and the business and property ownership of those in office is striking. In Kuwait, Qatar and the UAE the opulent, and sometimes ostentatious, lifestyles of the ruling elite are routine fodder for the international media. These excesses, opulent lifestyles and waste, 
are incompatible with Islamic teachings and are in sharp contrast to the lifestyles of general population and migrant workers who in some cases account for almost half the population in several of these countries. If these rulers were Western financial chief executive officers (CEOs) few would question their right to lavish bonuses. Being the heads of Islamic states, however, puts them in a unique position of being mandated to treat such depletable resources to benefit all citizens of this and future generations equally. As such, not only is excessive use of oil revenues for amassing personal wealth prohibited, but so are, among others, wasteful economic policies geared towards consumption, subsidies (instead of market and job creation), uncompetitive bidding and procurement contracts, favored business loans and licensing agreements, lack of fiscal and economic transparency, and lack of adequate savings and returns on the oil revenues to protect the interests of future generations.

In addition to the corruption associated with natural resources and its treatment in Islam, not unexpectedly other forms of corruption that are traditionally found in other developing countries are also present in the Persian Gulf. As a general rule, while corruption in the more developed countries tends to be generally more subtle, 'camouflaged' and long term in form, in the oil-exporting countries it tends to be more blatant and immediate ('cash on the barrel head' so to speak). Popular belief among the general public is that corruption is largely associated with economic underdevelopment and rent-seeking behavior, and the correlation of the high degree of political and economic (oil) corruption, in for example Nigeria, and the lack of economic development is well documented and researched. It should be noted that there is also considerably less research on corruption in more developed countries, and if one takes a deeper analytical look at the issues of corruption it becomes apparent that it exists in various forms in all countries, regardless of the level of economic development. Although not all rent-seeking behavior is corrupt, rent-seeking may often entail corrupt practices.

Even in the US, arguably the most industrialized country in the world with the most democratic and transparent system of government, it is relatively easy to point to political considerations that continue to contaminate the quality of economic and financial policies adopted by the US Congress, the White House, and other government agencies. For example, members of Congress, be they Republicans or Democrats, do not make decisions solely on the basis of what is in the interest of the American economy or, for that matter, the rest of the world when applicable, such as in the arena of global warming. They, in part, incorporate into their objective function factors such as winning elections - a task that may involve following through on campaign promises, exchanging political and economic favors 
to supporters in exchange for votes or campaign financing support. US politicians accept campaign donations and favors (exotic trips and noncash gifts) in return for support and favorable legislation, which ultimately means financial benefits. Individuals also accept political appointments which they in turn and over time transform into financial benefits, awarding contracts to companies now with the implicit understanding that they will receive financial benefits, such as lucrative employment, in the future (generally referred to as a 'revolving door' in Washington, DC). In the US it is rare, though not unheard of, that a politician will directly accept cash or a bank transfer and directly buy votes. The impact of economic policy decision-making at both the macro and micro levels could be better understood and forecasted if economic models could better capture some of the more subtle forms of corruption and rent-seeking behavior.

In many of the oil-exporting countries in the Persian Gulf, as in most impoverished or failed states, subtlety does not seem to be the modus operandi. This was particularly true during the 1980s. Ostentatious jet-setting lifestyles were financed by public oil revenues and other forms of corrupt practices, with little accounting or transparency.

In oil-exporting countries there is an additional twist to corruption. Government contracts are so large by non-oil-exporting developing country standards, income distribution so grossly skewed, and corruption seemingly more pervasive and open so that the average person eventually is discouraged from hard work. For a rational individual the incentive system is turned inside out. Instead of hard work and good investments (but not without risk) as the channels of advancement, the way to success is dependent on how to penetrate and join the circle of corruption and get a piece of the proverbial 'pie' with little or no risk. The 'democratization' of corruption increases with higher levels of poverty and more unequal distribution of incomes. While the poor and marginalized suffer disproportionately from corruption, for those who fall within the system of patronage untold energies are spent on getting to know someone who knows someone who is in a position to help them financially.

Most oil-exporting governments tend to use oil rents to provide employment guarantees in the public sector, leading to often non-value-added jobs with little room for advancement, and often bloated government bureaucracies that serve to entrench systemic corruption further and disenfranchise individual drive and ambition. The PGOEC are no exception. Research suggests that for natural resource-rich countries, the misallocation of talent from productive sectors of the economy to corrupt rent-seeking activities has had a negative impact on overall economic growth. ${ }^{28}$ Until the mid-1990s, the effort to create non-oil wealth and other revenue streams has been nominal in the PGOEC, for example, the lack 
of effective income tax systems. It should be noted that while Iran has the only long-standing income tax system in the region, it is largely ineffective. Corruption (that is, kickbacks, bribes and other corrupt behaviors) serves as an informal tax in the region; however, without the demands of accountability and transparency inherent in a formal system of taxation.

After the mid-1990s, many of the governments in the region faced the stark reality that if they did not begin to create reasonably functioning markets and meaningful jobs, their own survival was in jeopardy given the growing discontent in the population over the areas of economic progress and human development. This was in fact giving rise, and more influence, to religious leaders who were promising a more even distribution of oil wealth than the ruling elite. This was especially glaring due to the rate of oil depletion and lack of public savings over the last four decades under almost absolute rule in most of these countries. Many of the PGOEC languished rudderless in terms of an economic growth and diversification strategy for almost 30 years and then suddenly realized their lack of foresight. And because the oil revenues had been squandered and savings were proving insufficient to finance future generations, these governments began to realize the need to draw in foreign investments. Thus began the mega-construction projects in the UAE (in Dubai). Most of the PGOEC followed suit and have now attempted to adopt the elements of the 'Dubai Model $^{29}$ of economic growth, that is, growth through private (domestic and foreign) investment in the service, education and research and development (R\&D)-driven sectors after the oil has been depleted. ${ }^{30}$ Qatar, for example, has made its move to become a regional hub of higher education. Others, like Saudi Arabia, began to scramble and introduce economic and knowledge cities in the middle of the desert under its 10x10 Program. The goal of the 10x10 Program is to put Saudi Arabia among the world's top ten globally competitive investment destinations by 2010. The 2007-09 global financial meltdown has slowed these attempts to rectify 40 years of regional economic mismanagement and these governments are now again frantically attempting to design ways to pacify a growingly discontented and disillusioned population. This is, however, becoming increasing difficult given the global financial crisis and accompanying liquidity crunch and the attendant sharp drop in oil prices and oil revenues.

\section{Measuring Corruption in the Persian Gulf}

In this section we attempt to measure the manifestation of corruption in the Persian Gulf oil-exporting countries (PGOEC). We benchmark the PGOEC against a set of non-oil-exporting Islamic countries and major non-Islamic oil-exporting countries. ${ }^{31}$ We first view corruption from the 
political-economic standpoint and investigate the interactions between five of the most widely accepted direct and indirect indices of corruption. These are well established and globally recognized indices that can serve as direct proxies to demonstrate the existence of corruption. First, we consider what we know to be the three most popular and explicit corruption indices: the Control of Corruption Index, International Corruption Index, and Corruption Perception Index. To augment these direct measures of corruption we also use other indices that have elements of corruption in them, or are either associated or reflective of the various indicators for the existence of corruption. Second, we use indices that cover civil and political rights and economic freedom, such as Freedom in the World, Economic Freedom in the World, and Index of Economic Freedom. Third, we utilize the regulatory environment that controls business and investment as a proxy for the close association between corruption and good business environment and practices. In doing so, the study utilizes the well-known World Bank Ease of Doing Business Index. Fourth, we measure failure of governance (government) and corruption by using the World Bank Worldwide Governance Indicators. Lastly, while the linkages between human development and corruption may seem less obvious than the relationship between the business environment or governance and corruption, it has been found that corruption, institutional development and human capital formation are closely linked.

\section{Corruption indices}

We use three of the most popular corruption indices: the World Development Indicators Control of Corruption Index (CCI), ${ }^{32}$ the International Country Risk Guide's Corruption Index, ${ }^{33}$ and Transparency International's Corruption Perception Index (CPI). ${ }^{34}$

The World Development Indicators Control of Corruption Index (CCI) is part of its overall Worldwide Governance Indicators. ${ }^{35}$ The Control of Corruption Index 'measures the extent to which public power is exercised for private gain, including petty and grand forms of corruption, as well as "capture" of the state by elites and private interests. ${ }^{36}$ The International Country Risk Guide's Corruption Index focuses on political-level corruption, for over 100 countries, with a long time series. Transparency International's Corruption Perception Index (CPI) measures 'the perceived levels of public-sector corruption in a given country and is a composite index, drawing on different expert and business surveys. The index scores 180 countries on a scale from zero (highly corrupt) to ten (highly clean). ${ }^{37}$ In Table 1.5, we summarize the three key corruption indicators from 1996 to 2008 .

Looking at all three corruption indicators in Table 1.6, according to TI 
Table 1.5 Key Corruption Indicators, 1996-2008

\begin{tabular}{|c|c|c|c|c|c|c|c|c|c|}
\hline & \multicolumn{3}{|c|}{$\begin{array}{l}\text { WDI Control of } \\
\text { Corruption Index, } \\
\text { Percentile (ranked) }\end{array}$} & \multicolumn{3}{|c|}{$\begin{array}{l}\text { ICRG Corruption } \\
\text { Index }^{7}\end{array}$} & \multicolumn{3}{|c|}{$\begin{array}{l}\text { TI Corruption } \\
\text { Perception Index } \\
\text { (ranked) }\end{array}$} \\
\hline & $2007^{1}$ & $2003^{2}$ & $1996^{3}$ & 2008 & 2003 & 1996 & $2008^{4}$ & $2003^{5}$ & $1996^{6}$ \\
\hline \multicolumn{10}{|l|}{$P G O E C$} \\
\hline Iran & 37 & 46 & 20 & 2.0 & 2.0 & 4.0 & 141 & 78 & .. \\
\hline Iraq & 2 & 9 & 3 & 1.0 & 5.0 & 1.0 & 178 & 113 & .. \\
\hline Kuwait & 72 & 82 & 76 & 3.0 & 2.0 & 3.0 & 65 & 35 & .. \\
\hline Qatar & 82 & 75 & 54 & 2.5 & 2.0 & 2.0 & 28 & 32 & .. \\
\hline $\begin{array}{l}\text { Saudi } \\
\text { Arabia }\end{array}$ & 58 & 67 & 36 & 2.0 & 2.0 & 2.0 & 80 & 46 & .. \\
\hline $\begin{array}{l}\text { United } \\
\text { Arab } \\
\text { Emirates }\end{array}$ & 82 & 85 & 63 & 2.0 & 2.0 & 2.0 & 35 & 37 & .. \\
\hline \multicolumn{10}{|c|}{ Islamic Non-Oil Exporters } \\
\hline Jordan & 67 & 65 & 53 & 3.0 & 3.0 & 4.0 & 47 & 43 & 30 \\
\hline Lebanon & 31 & 41 & 49 & 1.0 & 1.0 & 2.0 & 102 & 78 &.. \\
\hline Morocco & 53 & 54 & 64 & 3.0 & 3.0 & 3.0 & 80 & 70 & .. \\
\hline Senegal & 38 & 46 & 35 & 2.5 & 2.5 & 3.0 & 85 & 76 & .. \\
\hline Tunisia & 60 & 70 & 55 & 2.0 & 2.0 & 3.0 & 62 & 39 & .. \\
\hline Turkey & 59 & 50 & 58 & 2.5 & 2.5 & 2.0 & 58 & 77 & 33 \\
\hline \multicolumn{10}{|c|}{ Non-Islamic Oil Exporters } \\
\hline Canada & 96 & 95 & 97 & 5.0 & 4.0 & 6.0 & 9 & 11 & 5 \\
\hline Mexico & 49 & 53 & 36 & 2.0 & 2.0 & 3.0 & 72 & 64 & 38 \\
\hline Norway & 95 & 97 & 100 & 5.0 & 5.0 & 6.0 & 14 & 8 & 6 \\
\hline Russia & 16 & 27 & 23 & 2.0 & 1.0 & 2.0 & 147 & 86 & 47 \\
\hline $\begin{array}{l}\text { United } \\
\text { Kingdom }\end{array}$ & 94 & 96 & 96 & 4.0 & 4.5 & 5.0 & 16 & 11 & 12 \\
\hline Venezuela & 10 & 10 & 24 & 1.0 & 1.5 & 3.0 & 158 & 100 & 48 \\
\hline
\end{tabular}

Notes:

Number of countries ranked:

WDI $-{ }^{1} 208 ;{ }^{2} 205 ;{ }^{3} 154$

ICRG $-{ }^{4} 180 ;{ }^{5} 133 ;{ }^{6} 54$

${ }^{7}$ Countries are not ranked for the ICRG Corruption index, numbers represent overall scores. Low scores represent more corruption.

Source: World Bank, ICRG, TI data. 
Table 1.6 Averages of the Three Key Corruption Indicators from 1996 to 2008

\begin{tabular}{lccc}
\hline & $\begin{array}{c}\text { WDI Control of } \\
\text { Corruption Index, } \\
\text { Percentile (rank) }\end{array}$ & $\begin{array}{c}\text { ICRG } \\
\text { Corruption } \\
\text { Index }\end{array}$ & $\begin{array}{c}\text { TI Corruption } \\
\text { Perception Index } \\
\text { (rank) }\end{array}$ \\
\hline PGOEC & 52.7 & 2.3 & 72.3 \\
Islamic Non-Oil & 52.7 & 2.5 & 65.3 \\
$\quad$ Exporters & 61.9 & 3.4 & 47.3 \\
Non-Islamic Oil & & & \\
$\quad$ Exporters & & & \\
\hline
\end{tabular}

Source: Derived from Table 1.1.

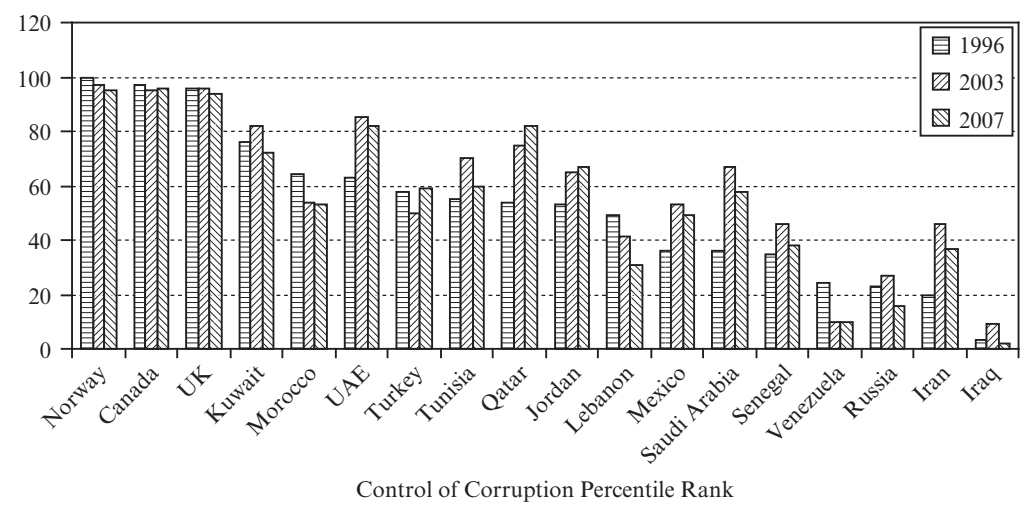

Source: World Bank data.

Figure 1.1 Evolution of Corruption, 1996-2007

rank and the ICRG index, corruption is on average higher in the Islamic oil-exporting (PGOEC) countries, followed closely by the Islamic nonoil-exporting group of countries; whereas according to the World Bank's Control of Corruption Index, corruption is on average higher amongst the Islamic non-oil-exporting countries, followed by the PGOECs. However, perception of corruption in the Islamic oil-exporting countries is less than that in the three developing oil-exporting countries (Mexico, Russia and Venezuela). Iraq, followed by Venezuela, is the most corrupt country in the study, while the Canada, the United Kingdom and Norway are the least corrupt.

Figure 1.1 illustrates the evolution of corruption from 1996 to 2007 
using the WDI's Control of Corruption Index. While the rank of the countries with the lowest levels of corruption appears to have remained consistent over time, the rank of those with higher corruption has been much more volatile. Qatar and Jordan are the only two countries that have consistently improved their score.

\section{Civil and political rights and economic freedom indices}

There are three well-known and established indicators that represent civil and political rights and economic freedom: Freedom in the World, Economic Freedom in the World, and the Index of Economic Freedom. The Freedom in the World survey, conducted by Freedom House, ${ }^{38}$ is an attempt to evaluate 'the state of global freedom as experienced by individuals'.$^{39}$ The Fraser Institute ${ }^{40}$ and Heritage Foundation ${ }^{41}$ have each developed an index, Economic Freedom in the World and the Index of Economic Freedom, respectively, to measure the extent to which policies and institutions are aligned with regards to the imperatives to economic freedom. While again these are not direct indicators of corruption per se, they do consider the various dimension of economic freedom which includes corruption.

Table 1.7 shows a snapshot of Civil and Political Rights and Economic Freedom Indicators from 1995 to 2007 for the 18 countries in our study.

Table 1.8 shows that on average in the oil-exporting non-Islamic group of countries there is a higher degree of political and civil freedom, followed by the non-oil exporters. On economic freedoms, with the exception of Russia and Venezuela, the oil-exporting non-Islamic group again rank amongst the most free, followed by the Persian Gulf oil exporters. That is to say, that while the institutions in major oil-exporting countries in the Persian Gulf may allow a relatively moderate degree of economic freedom, they are weak in terms of providing for basic political and civil liberties.

\section{Business environment index}

In recent years, there has been an increasing appreciation of the linkages between the quality of institutions, governance, business or investment climate and economic growth. Although sound macro-level economic policies are critical to economic development, institutional and regulatory factors may have an even more fundamental impact on prosperity. A direct result of good governance is an attractive business climate that encourages investment, provides incentives for private sector development, and creates jobs, thereby setting in motion new potentialities for economic growth. The World Bank's 2005 World Development Report (WDR) echoes this idea that enhancing the investment climate must be a principal feature of any sustainable development agenda. ${ }^{42}$ Moreover, there is clear evidence suggesting that there is a close association between corruption 


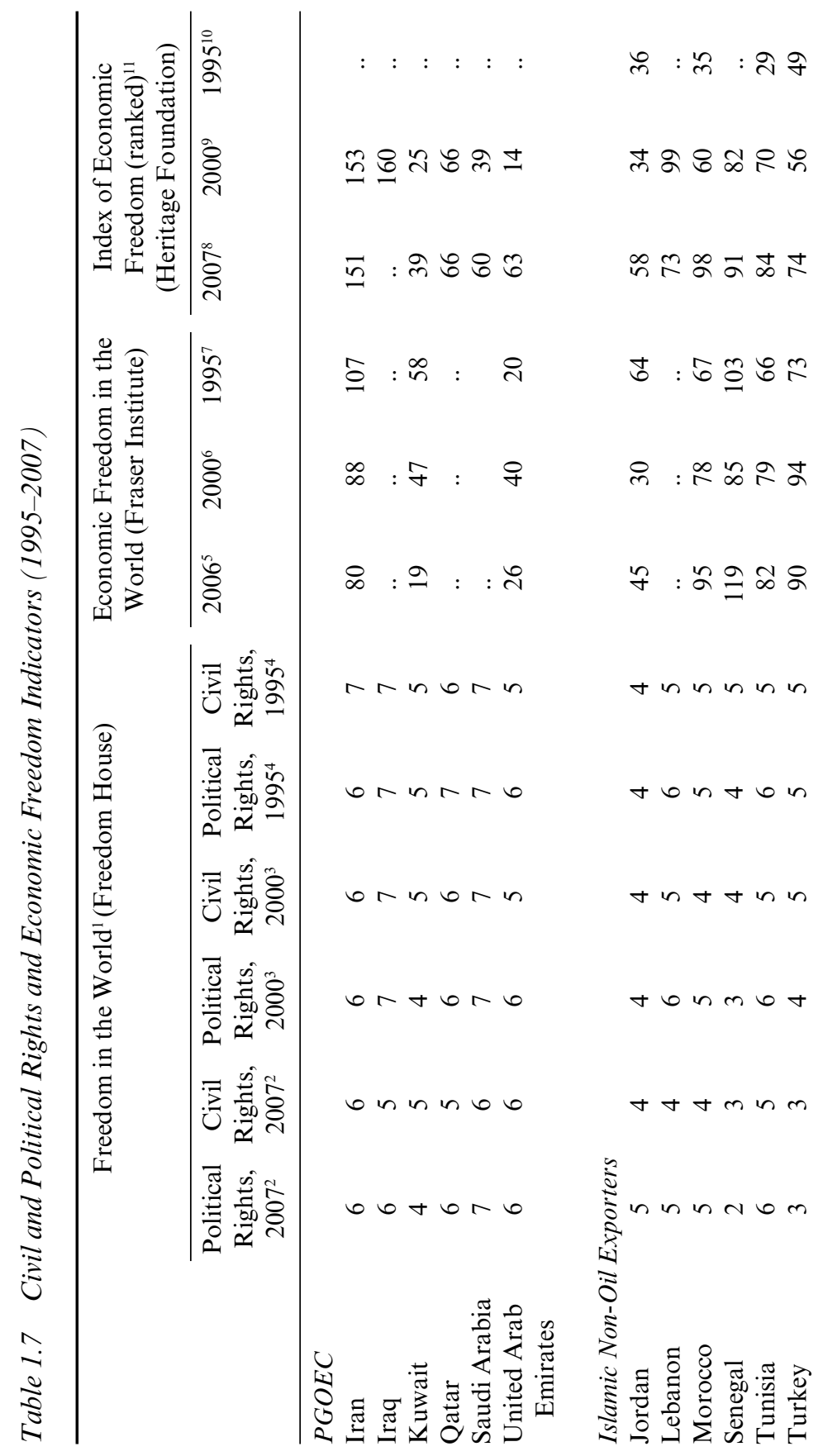




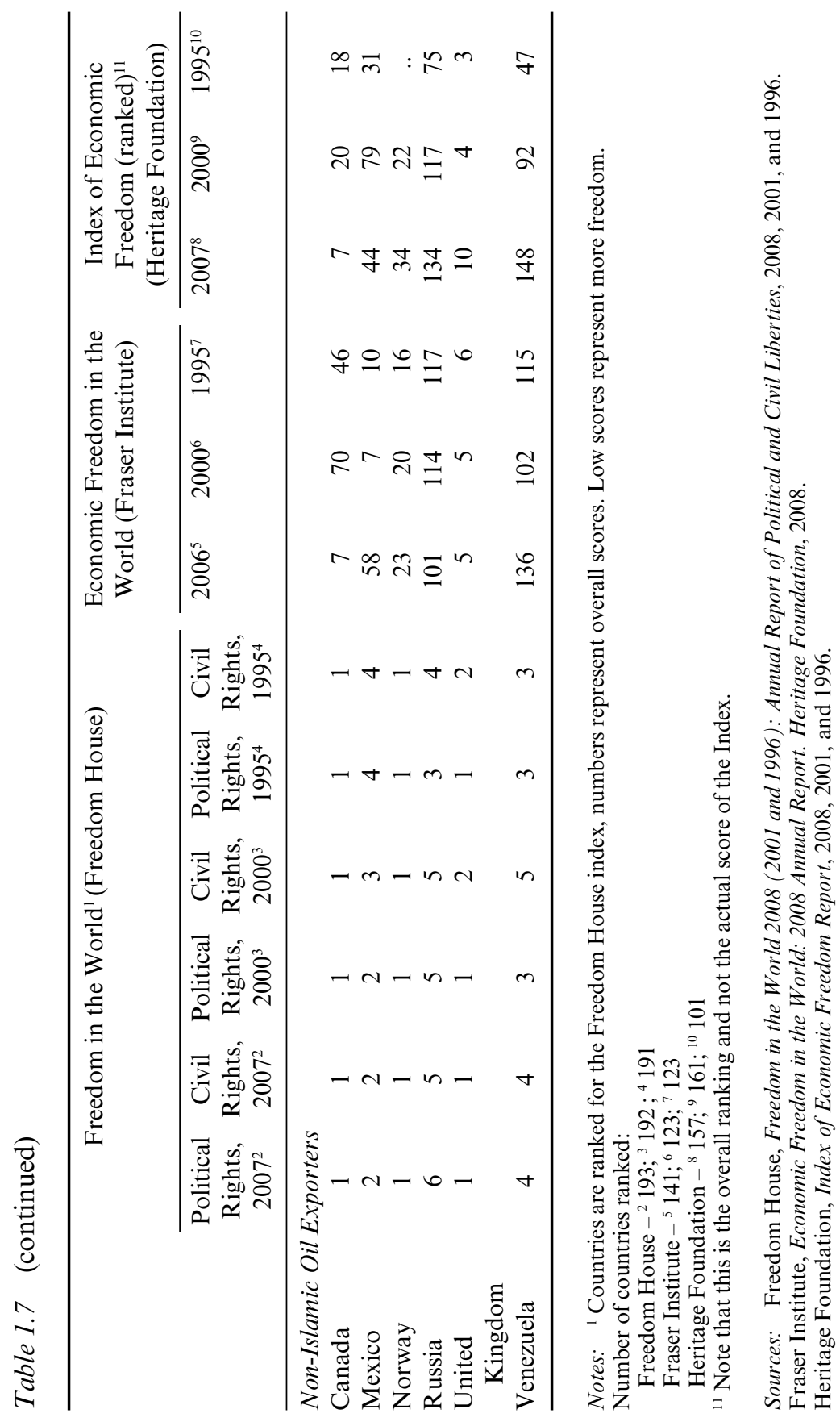


Table 1.8 Averaged Ranking for Civil and Political Rights and Economic Freedom Indicators, 1995-2007

\begin{tabular}{lccc}
\hline & $\begin{array}{c}\text { Freedom in the } \\
\text { World (Freedom } \\
\text { House) }\end{array}$ & $\begin{array}{c}\text { Economic } \\
\text { Freedom In the } \\
\text { World (Fraser } \\
\text { Institute) }\end{array}$ & $\begin{array}{c}\text { Index of Economic } \\
\text { Freedom (rank) } \\
\text { (Heritage } \\
\text { Foundation) }\end{array}$ \\
\hline PGOEC & 6.0 & 53.9 & 83.0 \\
Islamic Non-Oil & 4.5 & 78.0 & 66.7 \\
$\quad$ Exporters & 2.4 & 53.4 & 50.7 \\
Non-Islamic Oil & & & \\
$\quad$ Exporters & & & \\
\hline
\end{tabular}

and the regulatory environment that controls business and investment. For instance, a number of studies have found that countries with a heavier regulatory burden for business entry tend also to have significantly higher levels of corruption, in addition to larger informal economies and poorquality public and private goods. ${ }^{43}$ To some extent government regulations that impose barriers to business formation are enacted to give public officials the authority to demand and extract bribes, and as such tend to fuel corruption. ${ }^{44}$ Thus deregulation, coupled with mechanisms of transparency and accountability, may serve to limit abuse by public officials.

The question that naturally follows is how a country's business or investment climate should be measured. There are a number of crosscountry datasets including the World Bank's Doing Business indicators, which measure business regulations and their enforcement across 181 economies. Broadly, these indicators measure the regulatory costs of business and can be used to analyze specific regulations that enhance or constrain investment, productivity and growth in terms of the overall ease of doing business in a particular economy, based on a number of factors including the cost of doing business, and regulations on licensing, contract, employment and trade.

In our study we use the World Bank's widely used Doing Business indicators. In doing so we see that the PGOEC have a number of distortions and inefficiencies at the firm level, particularly in terms of the cost, time and number of procedures associated with: (1) starting a business; (2) dealing with licenses; (3) international trade; and (4) closing businesses. Table 1.9, the World Bank Ease of Doing Business 2008 rankings, provides rankings for all of the aggregate Doing Business indicators in the dataset.

Figures 1.2-1.8 provide a graphical view of the relationship between corruption and business environment for those variables where the 


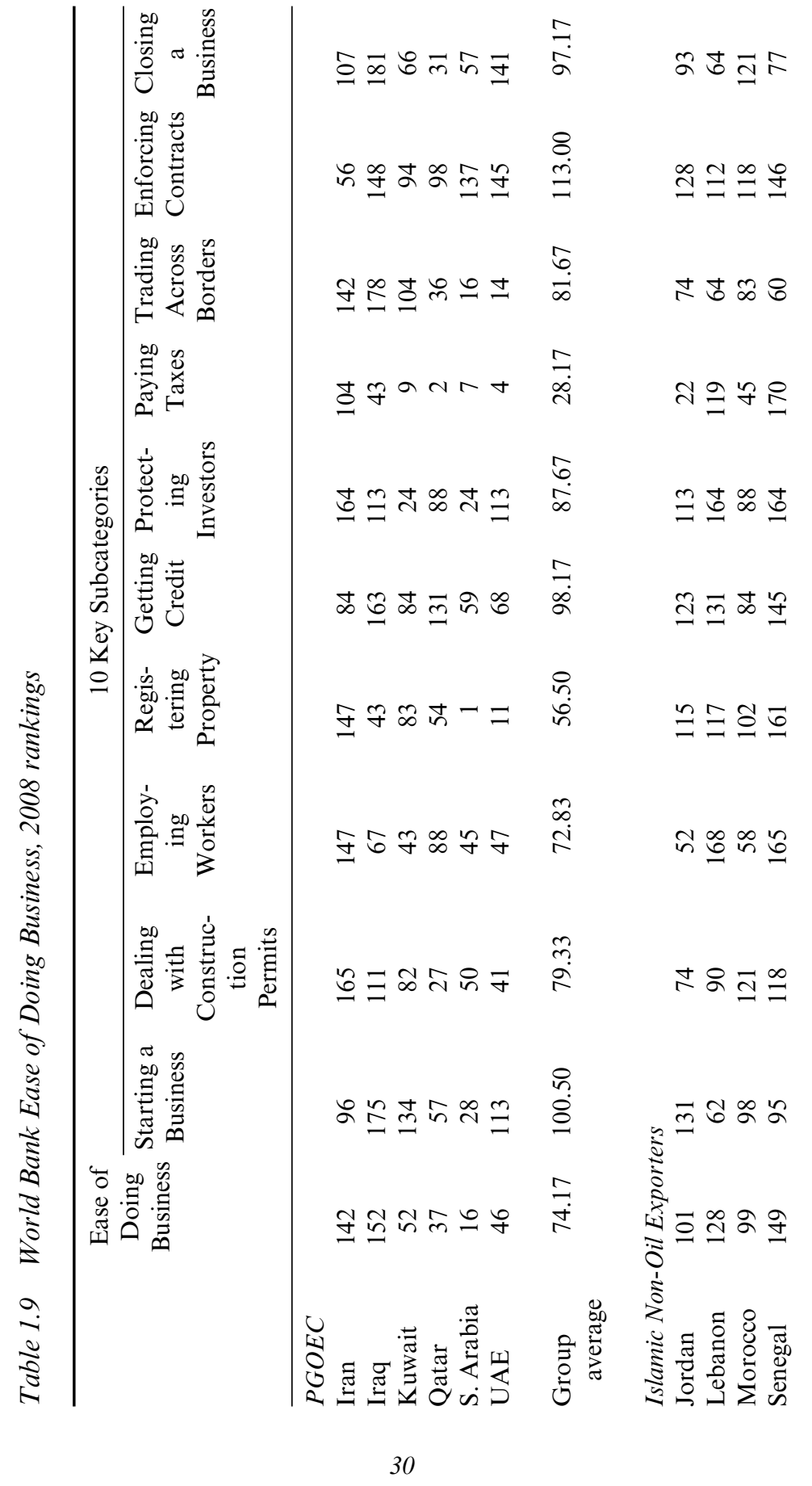




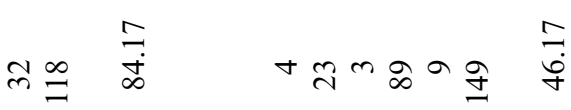

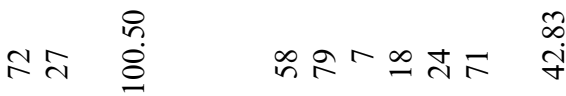

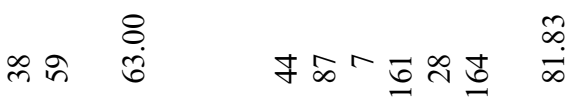

$\begin{array}{lll}m & m & 0 \\ 0 & \infty & \stackrel{8}{0}\end{array}$

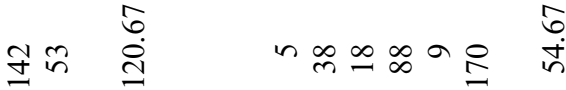

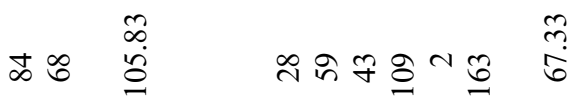

nं

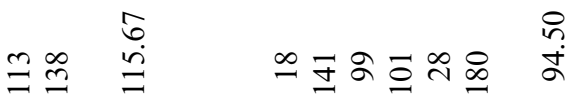

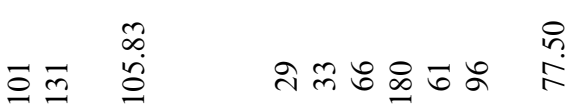

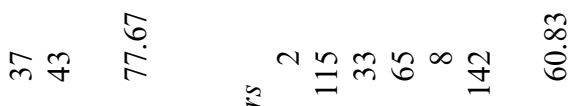

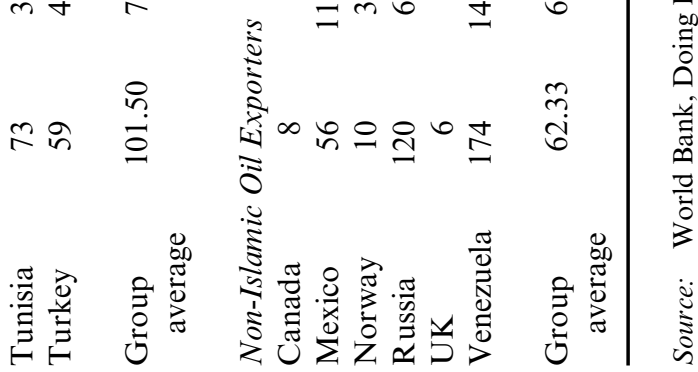




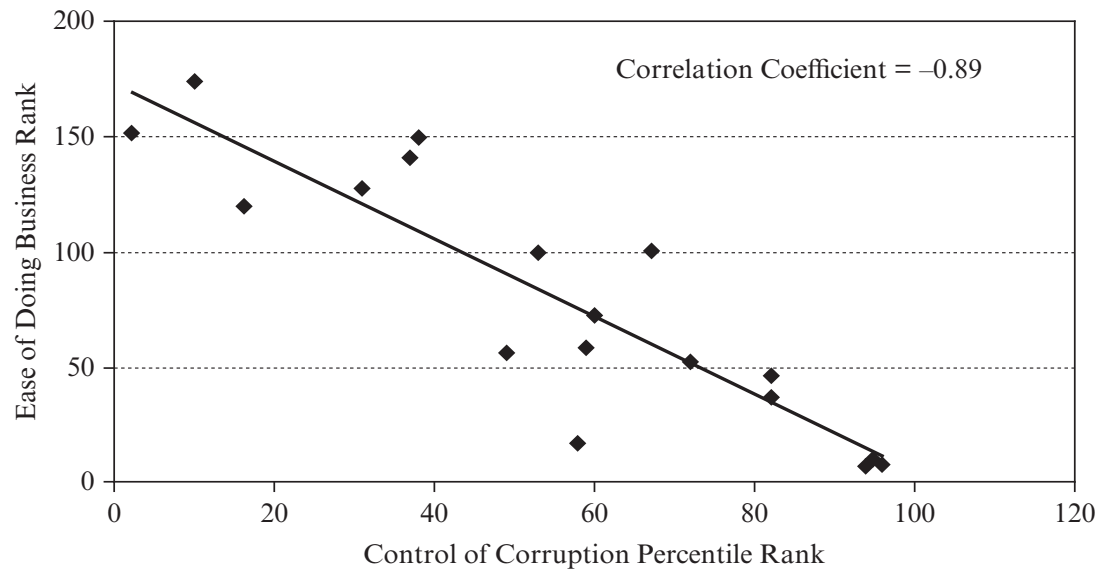

Source: World Bank, Doing Business Report, 2009.

Figure 1.2 Ease of Doing Business

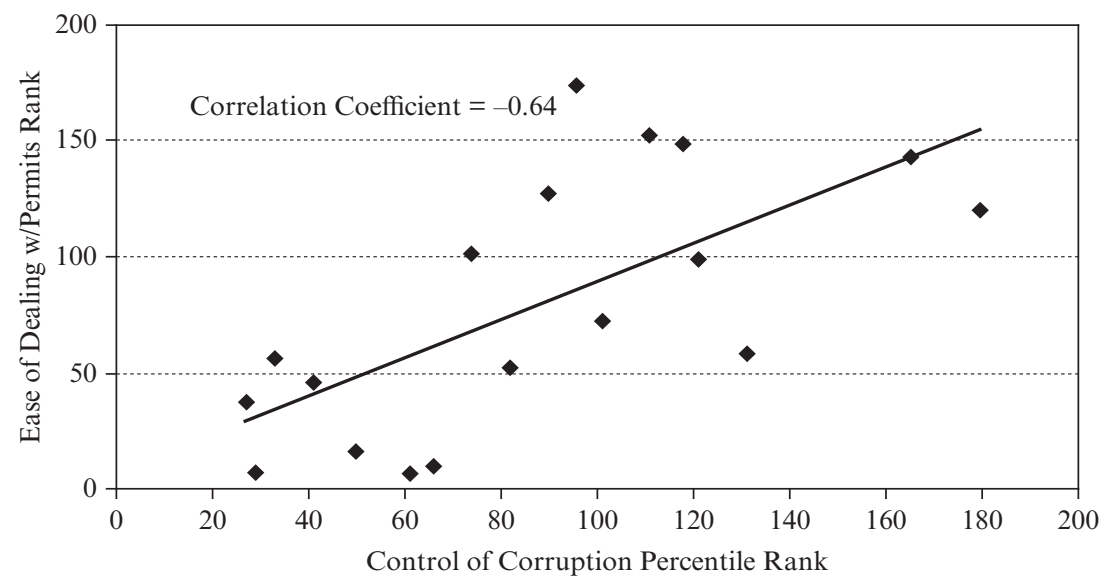

Source: World Bank, Doing Business Report, 2009.

\section{Figure 1.3 Dealing with Construction Permits}

correlation was significant (60+), including: the overall Ease of Doing Business, Dealing with Construction Permits, Getting Credit, Protecting Investors, Trading Across Borders, the Ease of Paying Taxes and Closing a Business. The overall business environment, measured by the ease of 


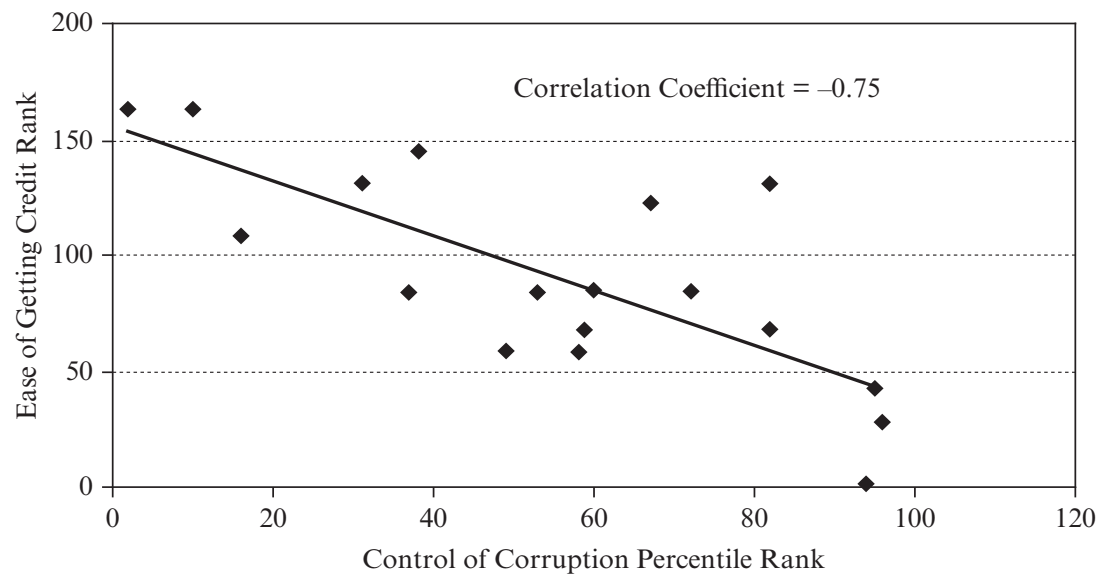

Source: World Bank, Doing Business Report, 2009.

Figure 1.4 Getting Credit Rank

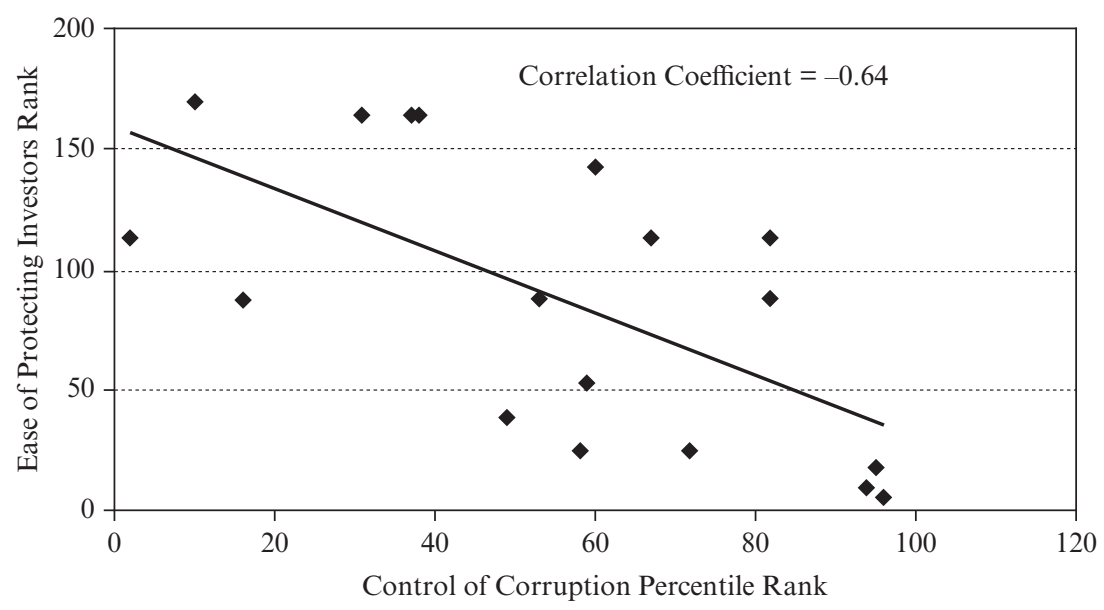

Source: World Bank, Doing Business Report, 2009.

Figure 1.5 Protecting Investors Rank

doing business, is poorest in Venezuela, however, closely followed by Iran, Iraq and Senegal.

Correlations between corruption and the Ease of Doing Business rankings supports evidence found in other bodies of research - for these 


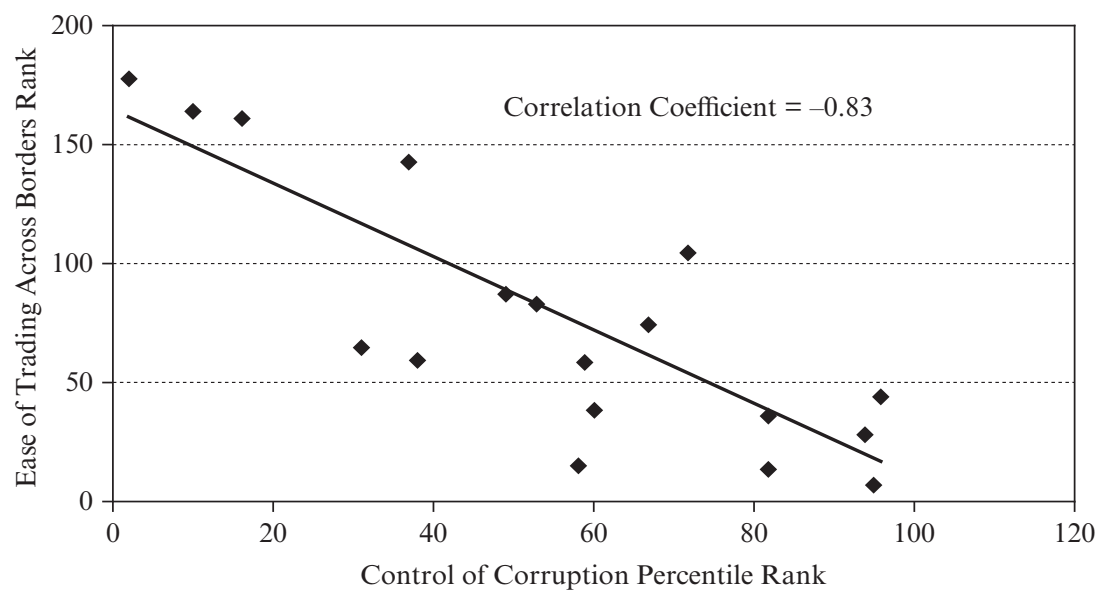

Source: World Bank, Doing Business Report, 2009.

Figure 1.6 Trading Across Borders Rank

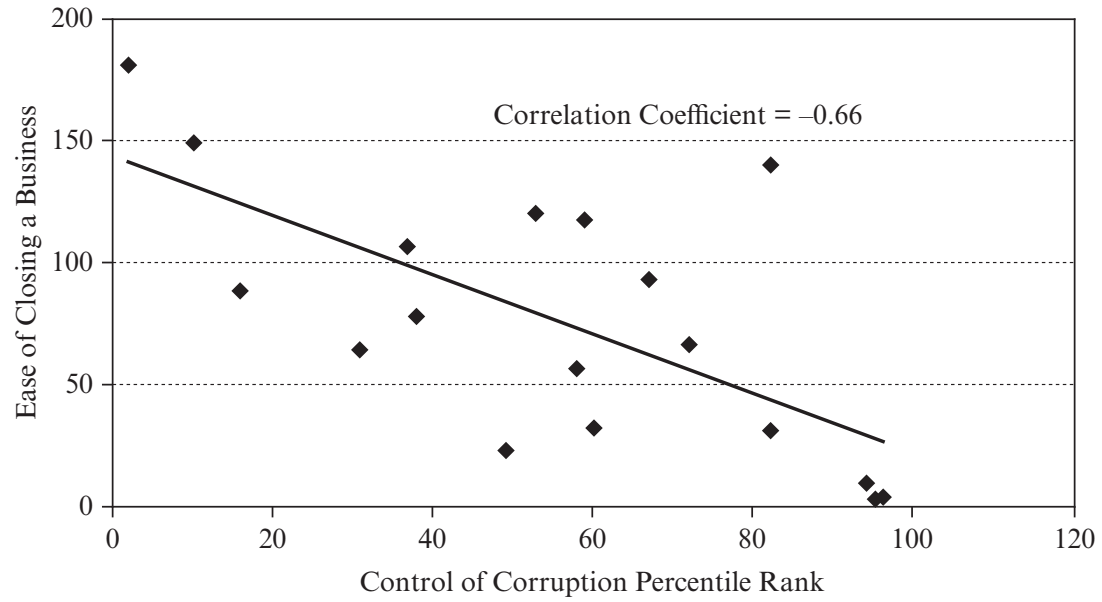

Source: World Bank, Doing Business Report, 2009.

\section{Figure 1.7 Closing a Business Rank}

groups of countries corruption is associated with the overall business environment $(-0.89)$. Similarly, a country's ranking in terms of Dealing with Construction Permits (0.64), Protecting Investors ( -0.64$)$, Getting Credit $(-0.75)$, Trading Across Borders $(-0.66)$, Closing a Business $(-0.66)$ and 


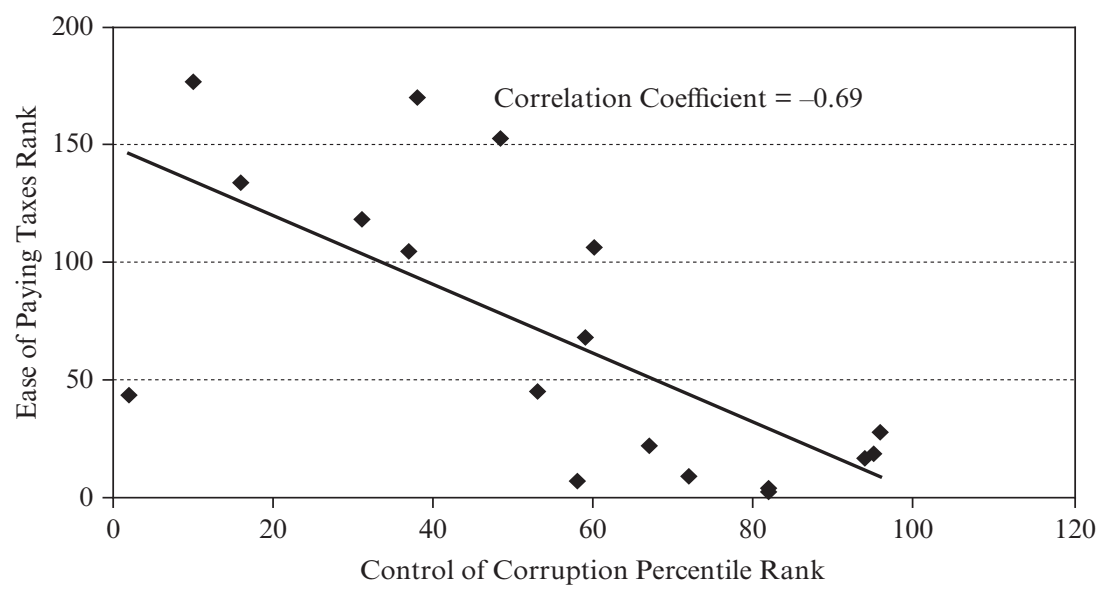

Source: World Bank, Doing Business Report, 2009.

Figure 1.8 Ease of Paying Taxes Rank

Paying Taxes $(-0.69)$ were also found to be correlated with corruption (based on the Control of Corruption percentile rank). That is to say, those economies that scored poorly in terms of the ease of doing business, such as Iran, Iraq, Senegal and Venezuela, also have relatively high levels of corruption. However, we also found that the corruption was not an accurate predictor of the other dimensions of the business environment (that is, starting a business and labor regulations).

\section{Good governance}

Most observers agree that, ultimately, widespread corruption is a sign of failure in governance. In most countries the common modalities of corruption, such as fraud, embezzlement, and the paying and receiving of bribes, are considered illegal. However, the issue of governance arises where governments fail to draw the legal line on what may be seen as borderline issues, such as state control of natural resources or limiting free-market mechanisms, where a select group may have disproportionate influence over public policy formulation. ${ }^{45}$ In some instances, the incidence of outright fraud or bribery may be low; however, ownership rights to public resources, such as oil in the case of the oil-exporting countries, may still not be adequately addressed by the regulatory or legal system.

Corruption has a tendency to gain momentum when it is out of public view and benefits only a small group; it is, as expected, threatened by mechanisms that are the hallmark of 'good governance' - transparency, 
accountability and inclusiveness. In resource-rich countries, corruption tends to translate to special access to natural resources, denying the wider population access to the country's wealth. Corruption within the ruling elite manifests itself as the desire to insure self-preservation as government leaders. And generally, institutions of governance are designed to promote and protect this objective. Their role as public servants in the first instance, in fact, factors little into the public policy decision-making process. In this sense, they are practicing perhaps the highest form of corruption that can be more adequately captured through a broader set of governance indicators, such as voice and accountability, political stability, government effectiveness, regulatory quality and rule of law.

Establishing mechanisms for good governance is a necessary step towards reducing corruption and sustaining some of the positive gains for political, socio-economic development. Ultimately, governments determine the allocation of societies' resources (including oil) via mechanisms of governance. See Table 1.10, World Bank Worldwide Governance Indicators, 2007 by rank. ${ }^{46}$

Table 1.10 shows that mechanisms that ensure voice and accountability, rule of law and regulatory quality are particularly weak amongst the Islamic oil exporters, with the exception of political stability. On voice and accountability, Iran, Iraq and Saudi Arabia rank amongst the lowest of the 18 countries in our study in terms of the extent to which their citizens are able to engage in the political process. It should be noted that in comparison to most other countries in our study, there is little evidence that much progress has occurred over the last decade in the Islamic oilexporting countries adequately to establish modalities essential for good governance.

\section{Human Development Index}

While the linkages between human development and corruption may seem less obvious than the relationship between the business environment or governance and corruption, many have actually found that corruption, institutional development and human capital formation are closely linked. For instance, education is essential to the development of an effective judicial system or for any other public institutions for that matter. Similarly, misuse of public funds by the government is more likely if a large portion of the population is uneducated or illiterate. ${ }^{47}$ See Table 1.11 for the United Nations' key Human Development Indicators.

Although not illustrated in Table 1.11, the Middle East and North Africa (MENA) region as a whole has made notable progress towards improving human development over the last few decades. For the oil economies of the Persian Gulf, human development (as measured by those 
Table 1.10 World Bank Worldwide Governance Indicators, 2007 Percentile Rank

\begin{tabular}{|c|c|c|c|c|c|}
\hline & $\begin{array}{c}\text { Voice \& } \\
\text { Accountability }\end{array}$ & $\begin{array}{l}\text { Political } \\
\text { Stability }\end{array}$ & $\begin{array}{l}\text { Government } \\
\text { Effectiveness }\end{array}$ & $\begin{array}{c}\text { Regulatory } \\
\text { Quality }\end{array}$ & $\begin{array}{c}\text { Rule of } \\
\text { Law }\end{array}$ \\
\hline \multicolumn{6}{|l|}{$P G O E C$} \\
\hline $\begin{array}{l}\text { Iran (Islamic } \\
\text { Republic } \\
\text { of) }\end{array}$ & 8 & 11 & 24 & 4 & 21 \\
\hline Iraq & 10 & 0 & 2 & 7 & 1 \\
\hline Kuwait & 34 & 60 & 63 & 61 & 71 \\
\hline Qatar & 28 & 76 & 58 & 67 & 80 \\
\hline Saudi Arabia & 7 & 25 & 51 & 52 & 59 \\
\hline $\begin{array}{c}\text { United Arab } \\
\text { Emirates }\end{array}$ & 23 & 73 & 79 & 72 & 70 \\
\hline $\begin{array}{l}\text { Group } \\
\text { average }\end{array}$ & 18.33 & 40.83 & 46.17 & 43.83 & 50.33 \\
\hline \multicolumn{6}{|c|}{ Islamic Non-Oil Exporters } \\
\hline Jordan & 27 & 34 & 65 & 62 & 65 \\
\hline Lebanon & 34 & 4 & 29 & 48 & 30 \\
\hline Morocco & 29 & 27 & 55 & 51 & 51 \\
\hline Senegal & 48 & 38 & 45 & 40 & 45 \\
\hline Tunisia & 13 & 47 & 69 & 57 & 60 \\
\hline Turkey & 42 & 21 & 64 & 60 & 53 \\
\hline $\begin{array}{l}\text { Group } \\
\text { average }\end{array}$ & 32.17 & 28.50 & 54.50 & 53.00 & 50.67 \\
\hline \multicolumn{6}{|c|}{ Non-Islamic Oil Exporters } \\
\hline Canada & 93 & 85 & 96 & 94 & 96 \\
\hline Mexico & 49 & 25 & 60 & 64 & 34 \\
\hline Norway & 99 & 93 & 99 & 90 & 100 \\
\hline $\begin{array}{l}\text { Russian } \\
\text { Federation }\end{array}$ & 20 & 23 & 42 & 35 & 17 \\
\hline $\begin{array}{l}\text { United } \\
\text { Kingdom }\end{array}$ & 94 & 66 & 94 & 98 & 93 \\
\hline Venezuela & 31 & 12 & 17 & 5 & 3 \\
\hline $\begin{array}{l}\text { Group } \\
\text { average }\end{array}$ & 64.33 & 50.67 & 68.00 & 64.33 & 57.17 \\
\hline
\end{tabular}

Source: World Bank, World Governance Indicators, 2008. 


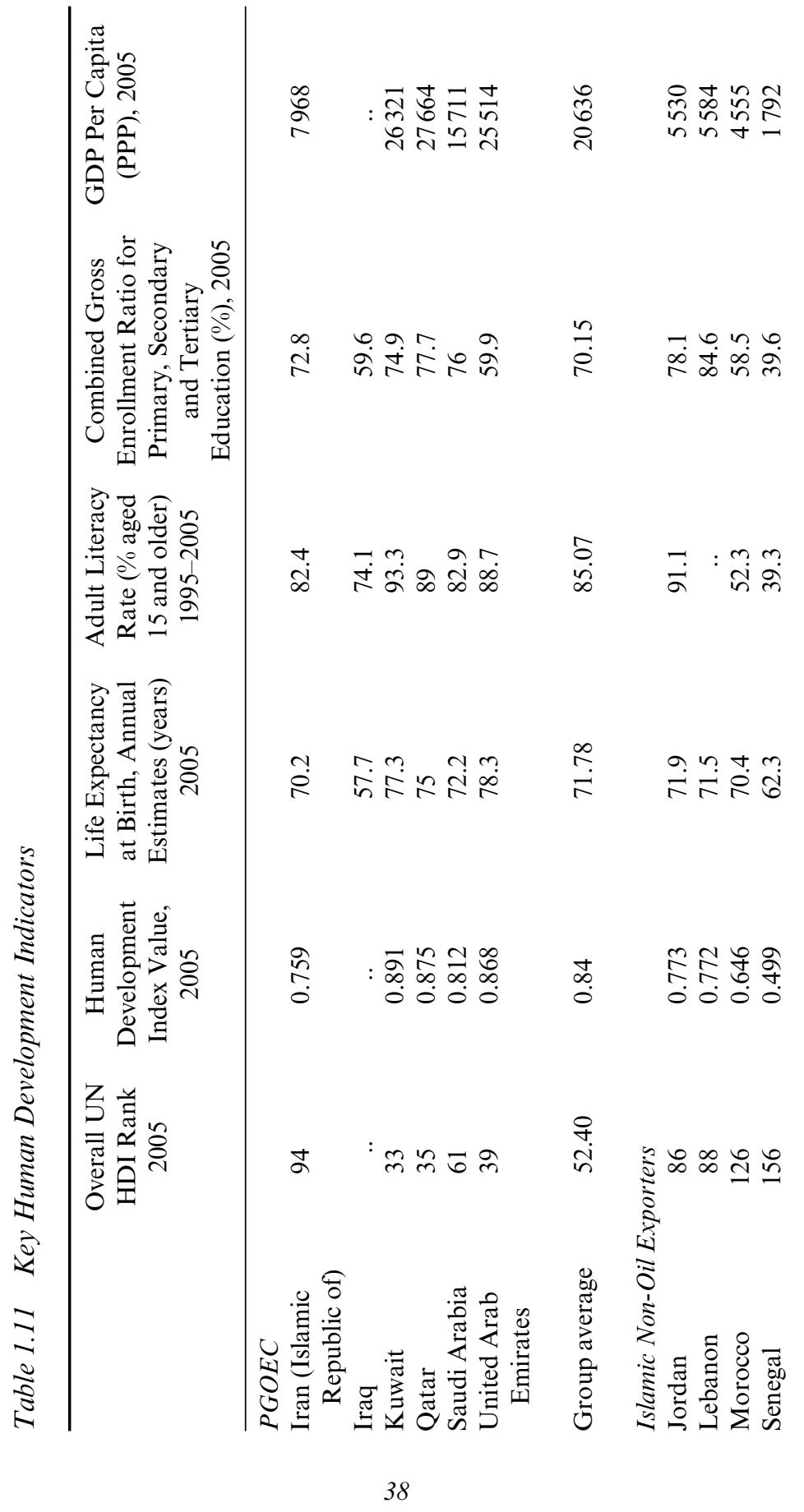




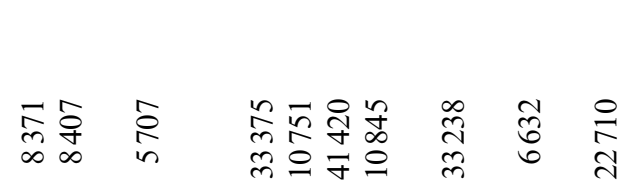

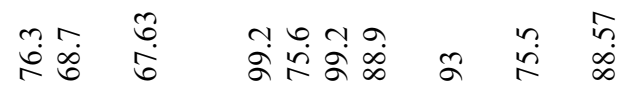

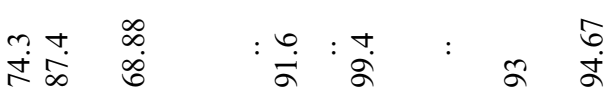

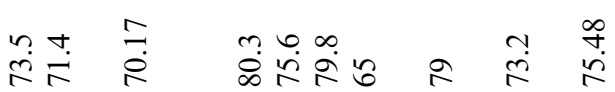

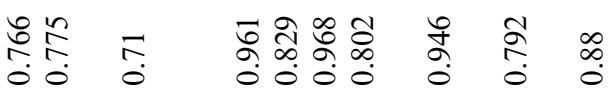

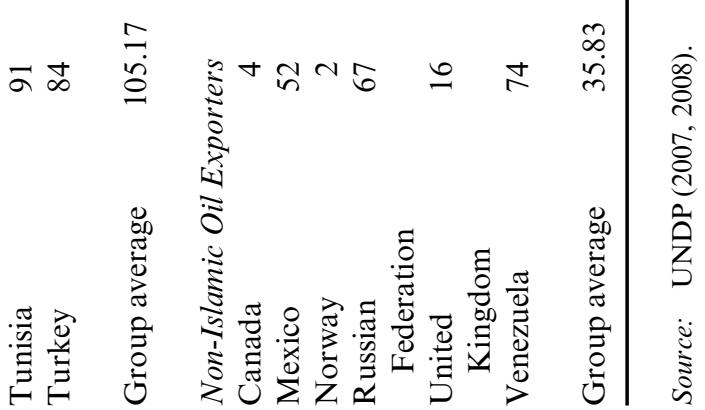




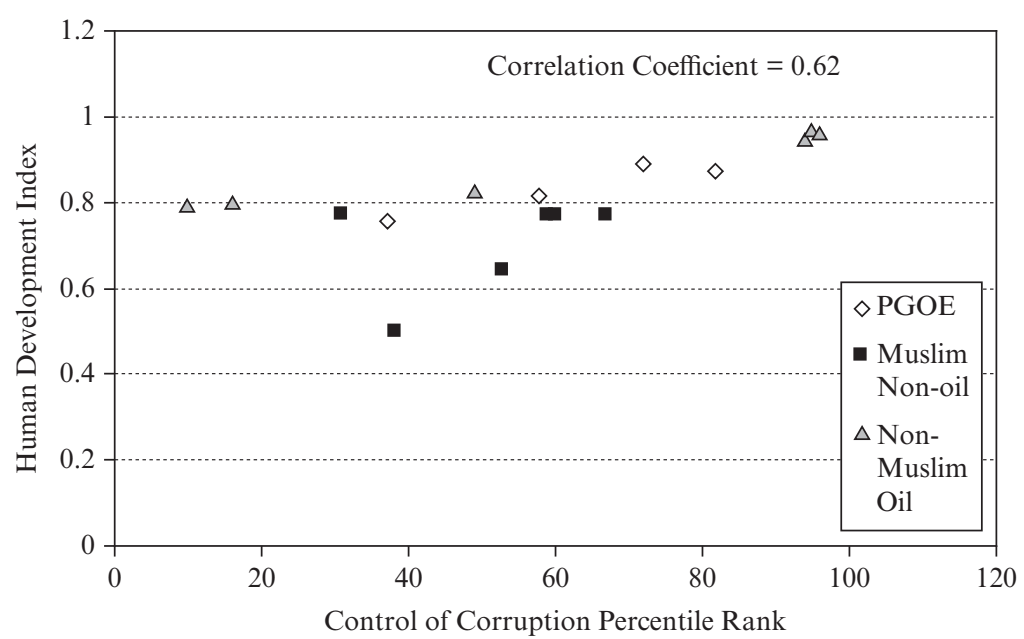

Source: $\operatorname{UNDP}(2007,2008)$.

\section{Figure 1.9 Human Development is Associated with Corruption}

variables included in the human development composite index $)^{48}$ tends to be more advanced than that of the non-oil-exporting countries in the region. However, the overall impact of corruption on human development in the MENA is difficult to support based on empirical evidence due to the dearth of relevant data and studies. As mentioned previously, in the oil-rich economies the effect of corruption on human development tends to be hidden as oil windfalls are used to subsidize generous social welfare programs in order to buy the support of the citizenry.

Of the three country groupings, the non-oil exporters on average have experienced lower levels of human development. Senegal and Morocco have the lowest life expectancy rate (with the exception of Russia), the highest infant mortality rate, the lowest youth and adult literacy rates, and the lowest HDI (Human Development Index) value.

On other specific measures of human development, Figures 1.9 and 1.10 shed some light on the association between corruption and HDI value, and corruption and life expectancy. Correlations between corruption and all the variables that make up the HDI suggest that countries with a high HDI value and a high life expectancy also have lower levels of corruption, whereas there is little association between corruption and the other three variables in the HDI composite. Based on the scatter diagram in Figure 1.9 , we can see that the non-Islamic oil exporters fall on either end of the extreme of the diagram, illustrating that these countries tend to have either 


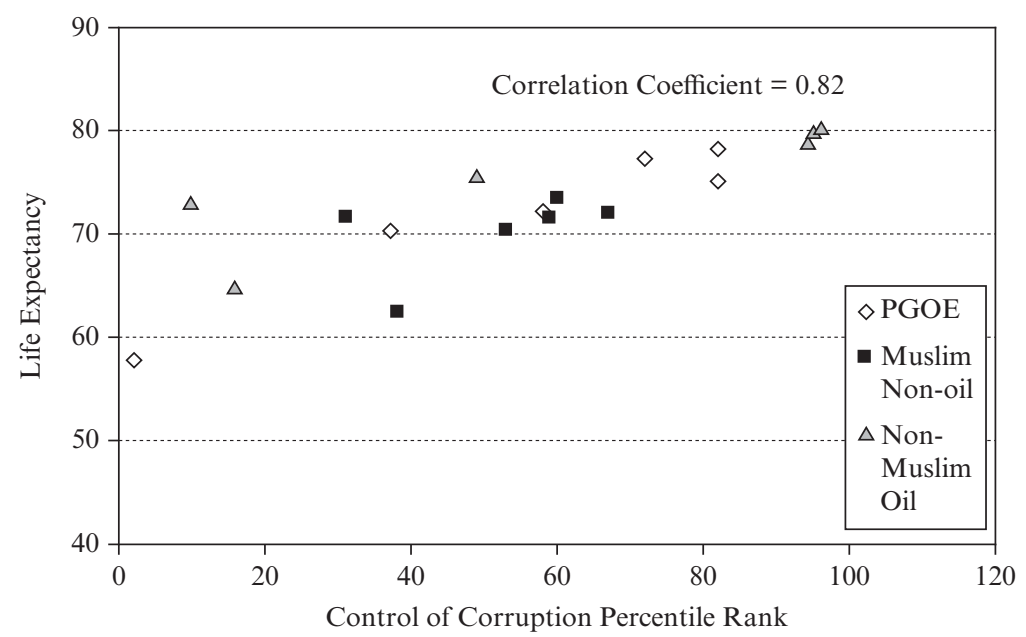

Source: UNDP $(2007,2008)$.

Figure 1.10 Life-Expectancy is Highly Associated with Corruption

high levels of corruption and a relatively low HDI value or vice versa; and for the PGOECs, HDI levels decrease almost uniformly as corruption levels increase (low on the Control of Corruption - $\mathrm{CC}$ - percentile rank). A very similar trend is seen in Figure 1.9 where for the PGOEC there appears to be a linear association between corruption and life expectancy; and the non-Islamic oil exporters tend to lie on either extreme with very low life expectancy and high corruption in some countries, or vice versa for others.

\section{CONCLUSION}

Overall the major oil-exporting countries of the Persian Gulf do not display a significantly higher level of perceived corruption than a comparable group of Islamic non-oil-exporting countries; and their perceived corruption level is somewhat lower than that for three selected developing oil-exporting countries chosen from outside the region. When we, however, look at some individual measurements such as the poor business environment, and weak mechanisms for good governance, we find manifestations of corruption are evident in oil-exporting countries of the Persian Gulf.

While oil reserves were plentiful, oil revenues could simultaneously 
subsidize the population, finance basic economic development and reward the ruling elite. This was particularly true of the richer countries of the Persian Gulf. This, however, is not sustainable in the longer term and only possible as long as the oil lasts and oil prices are high. Oil-enabled methods of governance are not sustainable because natural resources will be depleted over time and will eventually run out. Even while the oil lasts, short-run fluctuations in oil prices cause enormous problems for Saudi Arabia, Iran and Iraq given that they have not adequately structured policies to provide for oil revenue fluctuations. One solution is to adopt better governance and policies to achieve higher levels of sustained growth. Given the 2007-09 global crises coupled with the economic, social and political track record over the last 40 years, the political survival of some of these governments is now being called into question.

\section{NOTES}

1. Persian Gulf oil-exporting countries (PGOEC) include: Iran, Iraq, Kuwait, Qatar, the United Arab Emirates (UAE) and Saudi Arabia.

2. International Financial Institutions Anti-Corruption Task Force, World Bank, September 2006; http://siteresources.worldbank.org/INTDOII/Resources/FinalIFITaskForceFra mework\&Gdlines.pdf.

3. It was agreed that each of the member institutions (consistent with international conventions) would determine its own implementation within the boundaries of its charter.

4. International Financial Institutions Anti-Corruption Task Force, World Bank, September 2006, http://siteresources.worldbank.org/INTDOII/Resources/FinalIFITask ForceFramework\&Gdlines.pdf. p.1.

5. The OECD convention defines the bribery of foreign public officials as follows: 'the Convention defines the bribery of foreign public officials as the voluntary giving (promising or offering) of something of value to a foreign public official in order to obtain or retain business or other improper advantage in the conduct of international business. Bribery of domestic public officials is already a crime in the countries that are party to the Convention, as well as in most countries of the world. The Convention focuses on the person who offers, promises, or gives a bribe - "active" bribery; not with the recipient of the bribe - so-called "passive" bribery. A straight-forward case of bribery under the Convention can be illustrated as follows: A company officer from a country participating in the Convention (Country A) participates in a public tender in a foreign country (Country B). The officer meets with public officials from Country B and offers, promises, or pays, a substantial "amount" to "assist" the public officials in making their decision to award the officer's company the business contract in question. Under the Convention, it is also bribery whether money or some other type of advantage is offered, promised or given; whether the bribe was given directly or through intermediaries; whether the bribe was for the benefit of the foreign official or a third party; and whether the business receives in exchange a business contract or some other form of improper advantage, such as favorable tax treatment or a reduction in customs duty. It is clear that there are two sides to bribery. As the largest exporters of trade and investment in the world, multinationals represent, by far, the greatest potential source of bribe money. The supply side was a logical place for our countries to start, notably given that these countries are home to most multinational enterprises. However, the problem of 
the demand for bribes is not being neglected. The OECD promotes cooperation with a number of other regions of the world, and other international instruments also offer sound strategies to combat the demand side.' OECD, http://www.oecd.org/pages/ 0,34 17,en_36734052_36734103_1_1_1_1_1,00.html, accessed 1 July 2009; and http://www. odi.org.uk/PPPG/politics_and_governance/publications/vf_corruption_background_ note.pdf.

6. OECD, 2009. http://www.oecd.org/pages/0,3417,en_36734052_36734103_1_1_1_1_1, 00.html, accessed 1 July 2009; and http://www.odi.org.uk/PPPG/politics_and_govern ance/publications/vf_corruption_background_note.pdf.

7. 'Corruption and Anti-corruption Efforts: Research, Policy Highlights and Ways Forward.' Overseas Development Institute, United Kingdom, November 2006. http:// www.odi.org.uk/PPPG/politics_and_governance/publications/vf_corruption_backgro und_note.pdf.

8. World Bank, 'Strengthening World Bank Group engagement on Governance and Anticorruption', http://www.worldbank.org/html/extdr/comments/governance feedback/gacpaper.pdf.

9. World Bank, 'Strengthening World Bank Group Engagement on Governance and Anticorruption', http://www.worldbank.org/html/extdr/comments/governancefeed back/gacpaper.pdf, accessed 1 July 2009.

10. 'The IMF and Good Governance', Factsheet, Washington, DC, September 2008. http:// www.imf.org/external/np/exr/facts/gov.htm.

11. 'Asian Development Bank definition of corruption and fraudulent practices', Anticorruption and integrity main home page. http://www.adb.org/Integrity/faqs.asp.

12. '10. The system encourages good governance', World Trade Organization, 'Good Governance' website http://www.wto.org/english/thewto_e/whatis_e/10ben_e/10b10_e. htm.

13. Wittig (2003).

14. United Nations Development Programme, http://www.undp.org/governance/docs account/fighting_corruption_to_improve_governance.pdf.

15. Knack (2006).

16. Svensson (2005).

17. Leite and Weidmann (1999).

18. Knack and Keefer (1997).

19. Svensson (2005).

20. Knack (2006).

21. For example, Raaj (2007), Bardhan (1997) and Jain (2001).

22. Raaj (2007).

23. This is true for Kuwait, Qatar, Bahrain and the United Arab Emirates (UAE). Please note that for the remainder of this chapter Bahrain is not included in our discussion of PGOEC as it has not been an oil-exporting country for many decades.

24. Crystal (1989).

25. For more details see Askari and Taghavi (2005).

26. Mirakhor (2003).

27. Ibid. p. 25 .

28. Leite and Weidmann (1999).

29. The term 'Dubai Model' was coined by Scheherazade Rehman (with K. Dairabayeva) in "The "Dubai Model": A New Paradigm for Growth and Investment Strategies for Oil-Based Economies - Case Study Eurasia' (Rehman and Dairabeyeva, 2008).

30. See Wells (2005).

31. The countries in our study include our benchmark group of six Islamic major oil exporters located in the Persian Gulf - the PGEOC group (Iran, Iraq, Kuwait, Qatar, Saudi Arabia and the United Arab Emirates), six Islamic non-major oil comparator countries (Jordan, Lebanon, Morocco, Senegal, Tunisia and Turkey) which were selected based on three criteria: (a) a significant source of the countries' revenues did not come from oil; (b) they are members of the Organization of Islamic Conference 
(OIC); and (c) regional representation; and six oil-exporting non-Islamic comparators (Canada, Mexico, Norway, Russia, UK and Venezuela) represent those countries that are the largest oil producers and are not members of the OIC.

32. For more details please see Governance Matters 2009, Worldwide Governance Indicators 1996-2008. World Bank, http://info.worldbank.org/governance/wgi/index. asp.

33. For more details see Shah (2007).

34. Transparency International: for more details please see http://www.transparency.org.

35. The Worldwide Governance Indicators (WGI) project 'reports aggregate and individual governance indicators for 212 countries and territories over the period 1996-2007, for six dimensions of governance: Voice and Accountability, Political Stability and Absence of Violence, Government Effectiveness, Regulatory Quality, Rule of Law, and Control of Corruption. The governance indicators presented here aggregate the views on the quality of governance provided by a large number of enterprise, citizen and expert survey respondents in industrial and developing countries. These data are gathered from a number of survey institutes, think tanks, non-governmental organizations, and international organizations. The aggregate indicators do not reflect the official views of the World Bank, its Executive Directors, or the countries they represent. The WGI are not used by the World Bank Group to allocate resources or for any other official purpose.' Governance Matters 2009, Worldwide Governance Indicators 1996-2008. World Bank, http://info.worldbank.org/governance/wgi/index.asp.

36. Governance Matters 2009, Worldwide Governance Indicators 1996-2008. World Bank Governance home page, http://info.worldbank.org/governance/wgi/index.asp.

37. Transparency International, http://www.transparency.org.

38. The survey measures freedom as 'the opportunity to act spontaneously in a variety of fields outside the control of the government and other centers of potential domination', and is defined by two broad categories: political rights and civil liberties. Each of the 192 countries and 14 territories surveyed by Freedom House is assigned a numerical rating for political rights and a rating for civil liberties. A score of 1 indicates the highest degree of freedom and 7 the least. These ratings are then used to determine whether a country is classified as 'Free', 'Partly free', or 'Not free'. While this index does not provide a specific measurement for corruption, embedded in the survey are questions meant directly to address corruption as it relates to political freedom. More detailed information on Freedom House can be found at http://www.freedomhouse.org.

39. Freedom House, http://www.freedomhouse.org.

40. The Fraser Institute's 'Economic Freedom in the World' ranks a country's level of economic freedom based on five criteria where a lower score represents more freedom. It 'measures the degree to which the policies and institutions of countries are supportive of economic freedom. The cornerstones of economic freedom are personal choice, voluntary exchange, freedom to compete, and security of privately owned property. Forty-two variables are used to construct a summary index and to measure the degree of economic freedom in five broad areas: (1) size of government; (2) legal structure and security of property rights; (3) access to sound money; (4) freedom to trade internationally; and (5) regulation of credit, labor and business.' More detailed information on the Fraser Institute can be found at http://www.fraserinstitute.org.

41. The Heritage Foundation's Index of Economic Freedom ranks countries by considering a number of socio-economic-legal variables that fall into ten broader categories (business, trade, fiscal, monetary, investment, financial, labor freedom, property rights, freedom from corruption, and government size) using a scale of $0-100$, where 100 represents the maximum freedom. This index defines economic freedom in the following light: 'economic freedom is the fundamental right of every human to control his or her own labor and property. In an economically free society, individuals are free to work, produce, consume, and invest in any way they please, with that freedom both protected by the state and unconstrained by the state. In economically free societies, governments allow labor, capital and goods to move freely, and refrain from coercion or constraint 
of liberty beyond the extent necessary to protect and maintain liberty itself.' More detailed information on the Heritage Foundation can be found at http://www.heritage. org/Index/.

42. World Bank (2004).

43. Djankov (2002).

44. Svensson (2005).

45. Rose-Ackerman (2004).

46. Analysis is primarily based on the World Bank Worldwide Governance Indictors which categorize governance based on the following six broad indicators: (1) 'government effectiveness' and 'regulatory quality' summarize the ability of the government to formulate and implement sound policies; (2) 'rule of law' and 'control of corruption' measure respect for citizens and the state of the institutions which govern their interactions; (3) 'political stability and absence of violence' measures perception of likelihood that the government in power will not be destabilized as indicated by the continuity of policies; and (4) 'voice and accountability' captures the process by which citizens of a country are able to participate in the selection of their government representatives.

47. Svensson (2005).

48. The Human Development Index (HDI) is a composite index combining normalized measures of life expectancy, literacy, educational attainment and GDP per capita for countries worldwide. It is claimed to be a standardized means of measuring human development across countries. 